\title{
The CVDNOR project:
}

\section{Cardiovascular Disease in Norway 1994-2009}

\section{Description of data and data quality}

\author{
Jannicke Igland \\ Grethe S. Tell \\ Marta Ebbing \\ Ottar Nygård \\ Stein Emil Vollset \\ Tomislav Dimoski
}

July 2013 


\section{Table of Contents}

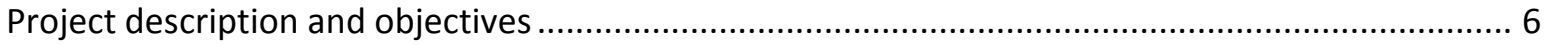

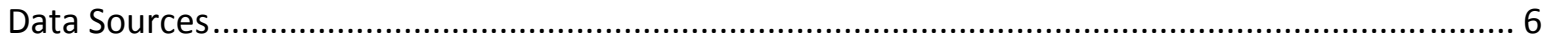

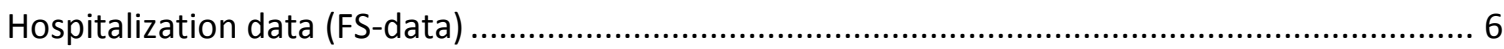

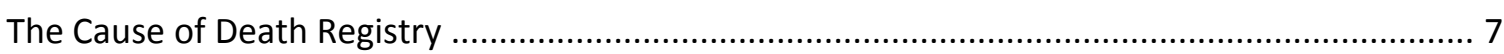

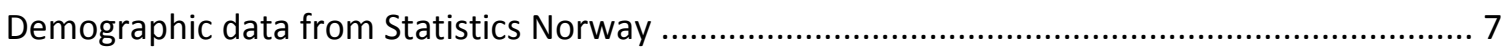

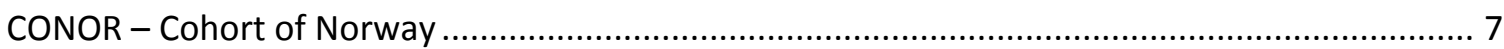

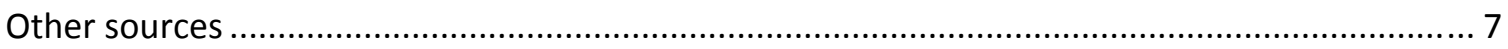

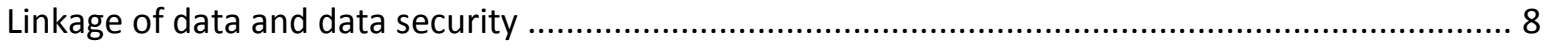

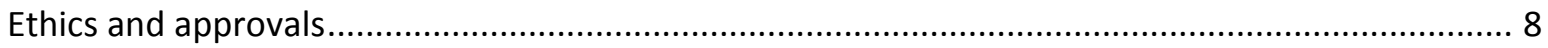

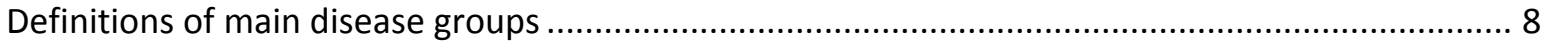

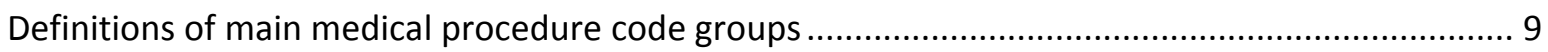

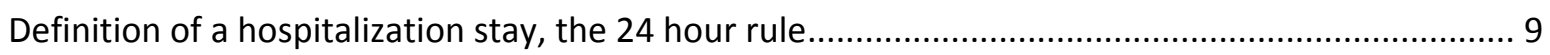

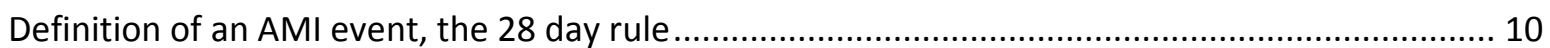

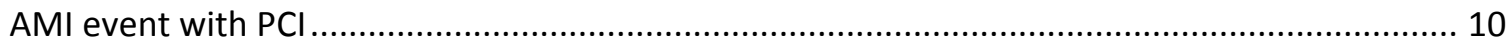

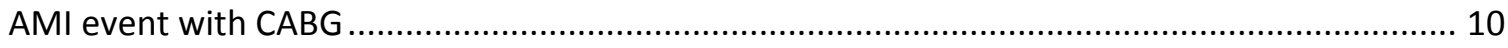

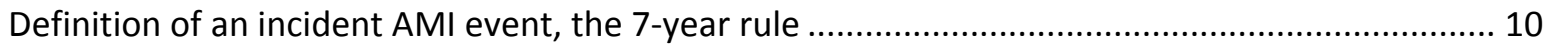

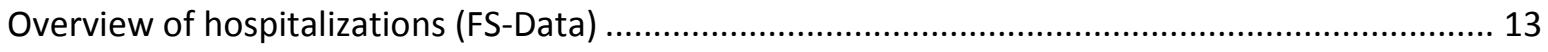

Hospitalization-data linked with demographic data and the Cause of Death Registry .................... 14

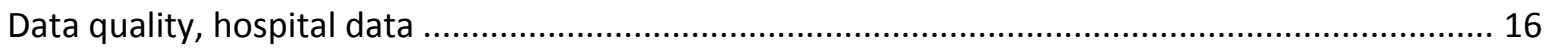

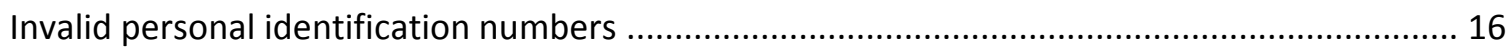

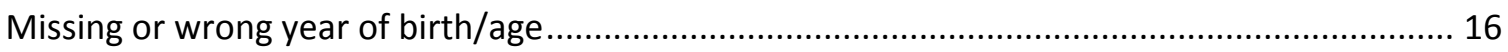

Missing and invalid municipality codes in hospital data .......................................................... 16

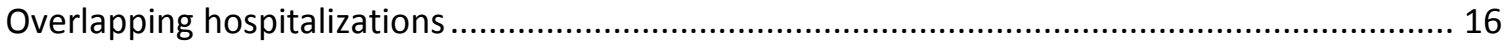

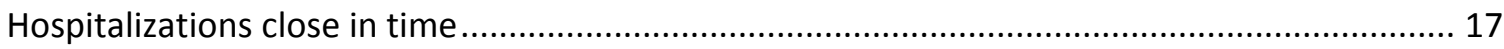

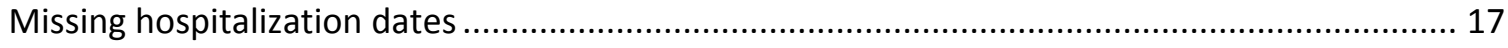

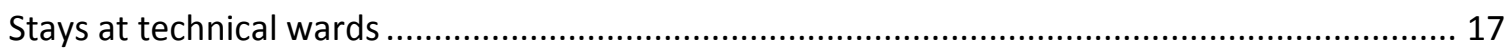


Comparison with data from the Western Norway Cardiovascular Registry (HKS-registeret) .......... 18

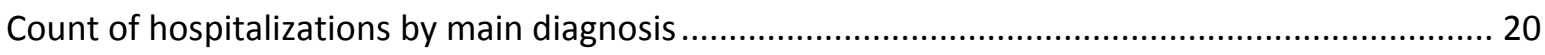

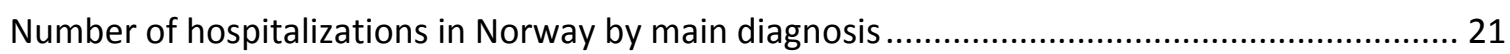

Hospitalizations with cardiovascular disease (CVD) as main diagnosis by hospital ...................... 22

Hospitalizations with coronary heart disease (CHD) as main diagnosis by hospital ..................... 23

Hospitalizations with acute myocardial infarction (AMI) as main diagnosis by hospital .............. 24

Hospitalizations with unstable angina pectoris (UAP) as main diagnosis by hospital .................. 25

Hospitalizations with acute coronary syndrome (ACS) as main diagnosis by hospital ................. 26

Hospitalizations with cerebrovascular disease (CEREBRO) as main diagnosis by hospital ............ 27

Hospitalizations with ischemic stroke (ISCHS ) as main diagnosis by hospital............................. 28

Hospitalizations with total stroke (TOTS) as main diagnosis by hospital ................................... 29

Hospitalizations with diabetes (DM) as main diagnosis by hospital ........................................... 30

Hospitalizations with atrial fibrillation (AF) as main diagnosis by hospital ............................... 31

Hospitalizations with hypertension (HT) as main diagnosis by hospital ...................................... 32

Hospitalizations with heart failure (HF) as main diagnosis by hospital..................................... 33

Hospitalizations with pre-eclampsia or eclampsia (PRECL) as main diagnosis by hospital............ 34

Hospitalizations with congenital heart defect (CongHeart) as main diagnosis by hospital ........... 35

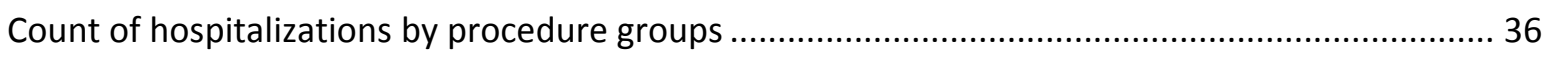

Count of total number of hospitalizations in Norway by procedure groups ............................... 36

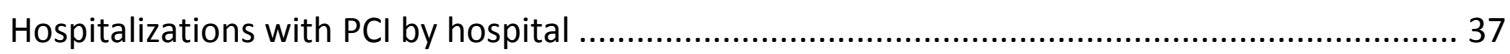

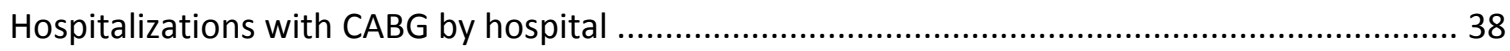

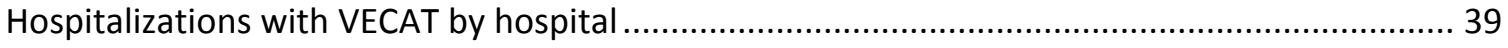

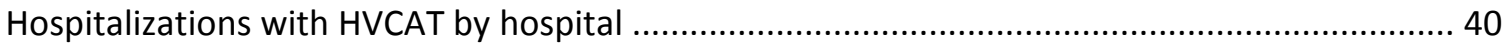

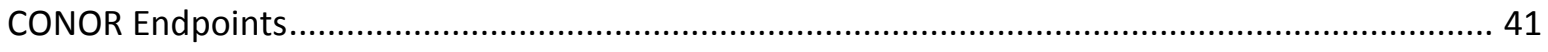

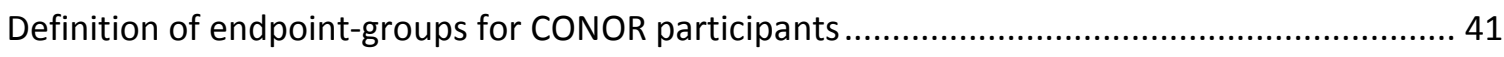

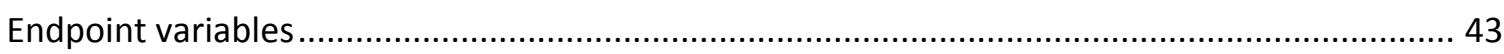


Count of fatal endpoints.

Count of combined endpoints, hospitalization or death ............................................. 46

Appendix A: Requirement Specification for retrieval of hospital data .................................... 47

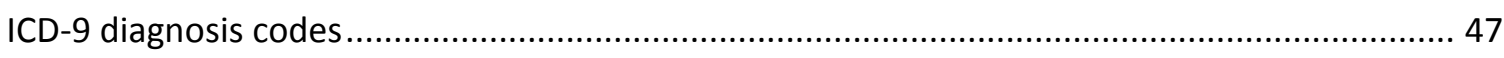

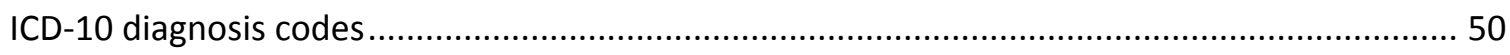

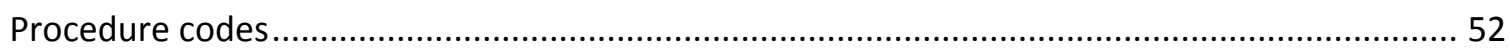

Appendix B: Overview of the linkage process ............................................................... 54

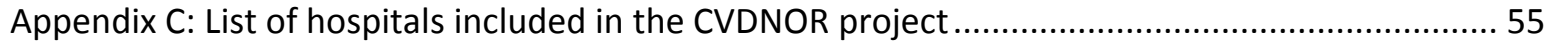

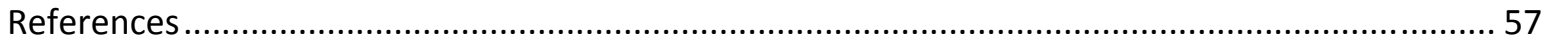


Table 1: Abbreviations used in the text

\begin{tabular}{|l|l|}
\hline Abbreviation & Explanation \\
\hline AA & Aorta aneurism \\
\hline AAS & Aortic aneurism surgery \\
\hline ACS & Acute Coronary Syndrome \\
\hline AF & Atrial fibrillation/ flutter \\
\hline AFP & $\begin{array}{l}\text { Atrial fibrillation procedures; electro conversion, } \\
\text { ablation and surgery }\end{array}$ \\
\hline AMI & Acute myocardial Infarction \\
\hline AS & Aorta stenosis \\
\hline ASS & Aortic stenosis surgery \\
\hline CABG & Coronay artery bypass surgery \\
\hline CEREBRO & Cerebrovascular disease \\
\hline CEREBRO & Cerebrovascular disease \\
\hline CHD & Coronary Heart Disease \\
\hline CongHeart & Congenital Heart Defects \\
\hline CONOR & Cohort of Norway \\
\hline CR & Coronary revascularization \\
\hline CVD & Cardiovascular disease \\
\hline CVDNOR & Cardiovascular disease in Norway \\
\hline DM & Diabetes Mellitus \\
\hline FS & Forskning i sykehus (=Research in hospitals) \\
\hline FS-data & $\begin{array}{l}\text { Data retrieved from the patient administrative } \\
\text { systems at the hospitals }\end{array}$ \\
\hline FS-system & $\begin{array}{l}\text { System used to retrieve data from the patient } \\
\text { administrative systems at the hospitals }\end{array}$ \\
\hline HF & Heart Failure \\
\hline HKS & $\begin{array}{l}\text { The Western Norway Cardiovascular Registry } \\
\text { (HKS-registeret) }\end{array}$ \\
\hline HT & Hypertension \\
\hline HVCAT & Left- or right-sided heart catheterizations \\
\hline ISCHS & Ischemic stroke \\
\hline PAS & Patient administrative system \\
\hline PCI & Percutaneous coronary intervention \\
\hline PRECL & Pre-eclampsia and eclampsia \\
\hline TOTS & Total stroke \\
\hline VECAT & Left-sided heart catheterization \\
\hline & \\
\hline
\end{tabular}




\section{Project description and objectives}

CVDNOR is a collaborative project between the University of Bergen and the Norwegian Knowledge Center for the Health Services. It is a research project with retrospective collection of data on CVD and Diabetes hospitalizations in Norway for the time period 1994-2009 linked with several other data sources.

The main objectives of the project are to study:

1. Trends in incident and recurrent events, prevalence, mortality and prognosis for different sub-groups of cardiovascular disease (CVD) in the total Norwegian population

2. Risk Factors and Lifestyle factors as predictors of incident and recurrent events and mortality

\section{Data Sources}

\section{Hospitalization data (FS-data)}

A system called FS (Forskning i Sykehus $=$ Research in hospitals) ${ }^{1}$ developed by Tomislav Dimoski at the Norwegian Knowledge Center for the Health Services was used to extract data from the electronic Patient Administrative Systems (PAS) at all somatic hospitals in Norway retrospectively for the years 1994 to 2009. Data included a unique ID-number for each patient (PS_fnr), age, gender and municipality code for the patient, dates of hospitalization and discharge, hospital code, main and secondary diagnoses, procedure codes, codes for departments and wards, dates for transfers between departments and wards and information about type of hospitalization (acute or elective). All hospitalizations containing at least one of the diagnosis codes or procedure codes from the requirement specification given in Appendix A were extracted. If one code fulfilled the requirement, all other diagnosis codes and procedure codes from that hospitalization were extracted. Briefly, the requirement specification included coded related to cardiovascular disease, diabetes, congenital heart defects and complications during pregnancy and labor which can be associated with cardiovascular disease, for instance pre-eclampsia.

The hospitalization data were delivered as one record per hospitalization. The hospitalization records were generated by combining ward stays to department stays and then further combination of department stays to a hospital stay. The main diagnosis for the hospitalization was set to be equal to the main diagnosis(according to the DRG-system) from the first ward stay. All other diagnoses were set to be secondary diagnoses. In some cases this will cause the main diagnosis to be different from the main diagnosis reported in the Nowegian Patient Register (NPR) for the same hospitalization since the main diagnosis in NPR is selected as the main diagnoses for the total hospitalization based on DRG-rules, not only the first ward-stay.

A list of the hospitals included in the project is given in Appendix C. 


\section{The Cause of Death Registry}

Website: $\underline{\text { www.fhi.no/helseregistre/dodsaarsakregisteret.no }}$

The cause of death data contains all deaths in Norway between 1994 and 2010. The data were delivered as one record per person and contains a unique ID-number for each person (PS_Fnr), gender, age at death, residency at death (municipality code), underlying and contributing causes of death, date of death, diagnostic basis and place of death (inside or outside an institution).

\section{Demographic data from Statistics Norway}

Website: www.ssb.no/a/english/mikrodata en.no

The received file contains information about all persons with a permanent address in Norway at any time between 1994 and 2009 (7.9 million records). The information includes a unique ID-number for each person, gender, birth year, date of death, information about citizenship, country of birth and country of origin. For each of the years 1994 through 2009, information includes residency (municipality code) as of January $1^{\text {st }}$, marital status, income, highest completed educational level as well as status januar $1^{\text {st }}$ for each year (alive and living in Norway/emigrated/ dead).

In addition we received a file containing the same information for the spouse for persons who were married or in a registered homosexual partnership.

\section{CONOR - Cohort of Norway}

Website: www.fhi.no/studier/cohort-of norway.no

Cohort of Norway (CONOR) is a collection of data from different regional health surveys in Norway carried out between 1994 and $2003^{2}$. Approximately 180000 individuals participated in at least one of the surveys. Information includes data from physical examination, analyses of blood samples and questionnaires. The physical examination included measurements of height, weight, hip and waist circumferences and blood pressure. The questionnaire included 50 standard questions on health status, lifestyle and diet, use of specific medications, educational level and occupational status. Nonfasting blood samples were analyzed for lipids and glucose. CONOR-data linked to hospitalizations and death in the CVDNOR-project is thus a unique source to study associations between various risk factors and later development of CVD or diabetes.

\section{Other sources}

The hospitalization data have also been linked to other data sources in various CVDNOR sub projects:

- The Medical Birth Registry

- BERTE Database

- The Cancer Registry

- WENBIT and NORVIT clinical trial data

- The Hordaland Health Studies and other health surveys 


\section{Linkage of data and data security}

Data from the different sources were linked and encrypted by Statistics Norway and at the Norwegian Knowledge Center for the Health Services. The personal identification number (unique for each Norwegian resident) was replaced by a unique ID called PS_fnr in all data files before these were sent to the University of Bergen.

Data from the different sources are stored as separate datasets on a secure windows server at the University of Bergen. The unique ID (PS_fnr) makes it possible to link the different data sources. Researchers with given privileges can log on to the server from their local computer via a Remote Desktop solution. The Statistical packages SAS, SPSS, Stata and R are installed on the secure server in addition to standard software such as Microsoft Office. All data processing is done on the secure server. It is not allowed to transfer data out of the server to local computers. Output-files from statistical analyses and other non-sensitive files can be transferred from the server to a local computer via a secure file-transfer server.

\section{Ethics and approvals}

The retrieval of data from PAS and linkage with causes of death, demographic data and CONOR were approved by the Regional Ethics Committee. The University of Bergen has permission to store the data until December $31^{\text {st }}$ 2018. In addition, all participants in CONOR have given written informed consent.

\section{Definitions of main disease groups}

Table 2: Definitions of main disease groups

\begin{tabular}{llll}
\hline Short name & Name & ICD9-codes & ICD10-codes \\
\hline CVD & Cardiovascular disease & $390-459$ & I00-I99 \\
CHD & Coronary heart disease & $410-414$ & I20-I25 \\
\hline AMI & Acute myocardial infarction & 410 & I21, I22 \\
ACS & Acute coronary syndrome & 410,411 & I20.0, I21, I22 \\
CEREBRO & Cerebrovascular disease & $430-438$ & I60-I69 \\
TOTS & Total stroke & $430-434,436$ & $160-161,163-164$ except I63.6 \\
ISCHS & Ischemic stroke & 433,434 & I63 except I63.6 \\
AA & Aorta aneurism & 441 & 171 \\
HT & Hypertension & $401-405$ & I10-I15 \\
AS & Aorta stenosis & 424.1 & I35.0, I35.2 \\
AF & Atrial fibrillation/ flutter & 427.3 & 148 \\
HF & Heart Failure & 428 & I50 \\
DM & Diabetes Mellitus & 250 & E10-E14 \\
PRECL & Pre-eclampsia and eclampsia & $642 .-642.7$ & O11, O14, O15 \\
CongHeart & Congenital Heart Defects & $745-747$ & Q20-Q28 \\
\hline
\end{tabular}




\section{Definitions of main medical procedure code groups}

Table 3: Definitions of main medical procedure code groups

\begin{tabular}{|c|c|c|c|}
\hline Short name & Name & SIF & $\begin{array}{l}\text { NCSP/NCMP, versions } \\
1994-2009\end{array}$ \\
\hline $\mathrm{PCl}$ & $\begin{array}{l}\text { Percutaneous coronary } \\
\text { intervention }\end{array}$ & $3294,3236,3239$ & $\begin{array}{l}\text { FNG02, FNG05, } \\
\text { FNOB00 }\end{array}$ \\
\hline CABG & $\begin{array}{l}\text { Coronary artery bypass } \\
\text { grafting }\end{array}$ & $3112-3129$ & $\begin{array}{l}\text { FNA, FNB, FNC, FND, } \\
\text { FNE, FNF }\end{array}$ \\
\hline CR & $\begin{array}{l}\text { Coronary } \\
\text { revascularization }\end{array}$ & $\begin{array}{l}3112-3129, \\
3294,3236,3239\end{array}$ & $\begin{array}{l}\text { FNA, FNB, FNC, FND, } \\
\text { FNE, FNF, FNG02, } \\
\text { FNG05, FNOB00 }\end{array}$ \\
\hline VECAT & $\begin{array}{l}\text { Left-sided heart } \\
\text { catheterization }\end{array}$ & $3235,3238,3291$ & $\begin{array}{l}\text { XF911, XF912, XF914, } \\
\text { FYDB }\end{array}$ \\
\hline HVCAT & $\begin{array}{l}\text { Left- or right-sided } \\
\text { heart catheterizations }\end{array}$ & $\begin{array}{l}3235,3238,3290, \\
3291\end{array}$ & $\begin{array}{l}\text { XF9101-XF904, XF911- } \\
\text { XF914, FYDB }\end{array}$ \\
\hline ASS* & Aortic stenosis surgery & & $\begin{array}{l}\text { FDG00, FDG10, FDG96 } \\
\text { FMA00, FMA10, } \\
\text { FMA20, FMA32, } \\
\text { FMA96 } \\
\text { FMB00, FMB10, } \\
\text { FMB20,FMB96 } \\
\text { FMD00, FMD10, } \\
\text { FMD12, FMD13, } \\
\text { FMD20, FMD30, } \\
\text { FMD33, FMD96 }\end{array}$ \\
\hline AAS & $\begin{array}{l}\text { Aortic aneurism } \\
\text { surgery }\end{array}$ & $3138-3143,8807-8807$ & $\begin{array}{l}\text { FCA, FCB, FCC, FCD, } \\
\text { PCG10, PDG10, } \\
\text { PDG20-24 }\end{array}$ \\
\hline AFP** & $\begin{array}{l}\text { Atrial fibrillation } \\
\text { procedures; electro } \\
\text { conversion, ablation } \\
\text { and surgery }\end{array}$ & 3190-3199 & $\begin{array}{l}\text { TF924/FPGX24 } \\
\text { 1FP59AC, FPFE24, } \\
\text { FPFE35, FPFE40, } \\
\text { FPB20, FPB22, FBP32 } \\
\text { FPD00, FPD96 }\end{array}$ \\
\hline
\end{tabular}

* The procedure codes are considered as aortic-stenosis surgery only if at least one of the following diagnosis codes is reported for the same patient: 1060, 1062, 1350, 1352, Q230, Q244, Q253.

**Considered as treatment for atrial fibrillation only if the patient has atrial fibrillation as main or secondary diagnosis.

\section{Definition of a hospitalization stay, the 24 hour rule}

The hospitalization data include transfers between hospitals, re-hospitalization at the same hospital shortly after the previous hospitalization and also some overlapping hospitalizations for the same patient.

When counting hospitalizations on the national level, a hospitalization stay for a patient is defined as a chain of hospitalizations in the following way: If a new hospitalization starts within 24 hours after the previous one ends, it should be classified as belonging to the first hospitalization, regardless of whether both hospitalizations occurred in the same hospital or not. The same should apply if the 
current hospitalization overlaps partly or completely with the previous one. The hospitalizations are then merged and the hospitalization date is set to be equal to the hospitalization date for the first hospitalization in the chain while the discharge date for the last hospitalization in the chain is set to be the discharge date for the new merged hospitalization. If a new hospitalization starts more than 24 hours after the previous hospitalization ends, it should be defined as a new hospitalization. When applying this rule on all hospitalizations fulfilling the inclusion criteria in CVDNOR, the maximum number of hospitalizations in a merged chain was 144 hospitalizations, but $91 \%$ of the chains contained only one hospitalization and $99.9 \%$ of the chains had $\leq 5$ hospitalizations.

When counting hospitalizations separately for each hospital, re-hospitalizations within 24 hours are only merged if both hospitalizations occur at the same hospital.

\section{Definition of an AMI event, the 28 day rule}

When counting AMI-events for a patient the first event is set to be the first AMI-hospitalization for this patient. The second event is the first hospitalization occurring $>28$ days after the first event. If a patient has two or more hospitalizations with an AMI-diagnosis within 28 days, all count as being part of the same event. The third event is the first hospitalization occurring $>28$ days after the second event etc. The number of AMI-events per year is given in Figure 1 and is always less than the number of AMI-hospitalizations per year.

\section{AMI event with PCI}

If a patient has a $\mathrm{PCl}$ procedure code during the same hospitalization as the AMI-event or during another hospitalization within 28 days from the hospitalization date for the hospitalizations where the event occurred, the $\mathrm{AMI}$ event is defined as an $\mathrm{AMI}$-event with $\mathrm{PCl}$. If the patient has a hospitalization with $\mathrm{PCl}>28$ days after the $\mathrm{AMI}$-event or no $\mathrm{PCl}$, the $\mathrm{AMI}$ event is defined as an $\mathrm{AMI}$ event without $\mathrm{PCl}$.

\section{AMI event with CABG}

If a patient has a CABG procedure code during the same hospitalization as the AMI-event or during another hospitalization within 8 weeks, the AMI event is defined as an AMI-event with CABG. If the patient has a hospitalization with CABG $>8$ weeks after the AMI-event or no $\mathrm{PCl}$, the $\mathrm{AMI}$ event is defined as an AMI event without CABG.

\section{Definition of an incident AMI event, the 7-year rule}

An incident AMI event is defined as a hospitalization with AMI as main or secondary diagnosis or AMI as underlying cause of death without any AMI hospitalizations during the last 7 years before the hospitalization date or date of death.

The ideal definition of an incident AMI event is an AMI event without any previous AMI events for the patient. However, because we do not have information before 1994, the patient's earlier disease history is not known. In accordance with previous studies ${ }^{3,4}$ we therefore decided to use a washoutperiod for all patients to look for previous AMI-events. In order to avoid bias when looking at timetrends ${ }^{5}$ we used a fixed 7-year time window backwards in time for all patients, even though a longer look-back period than 7 years was available for patients with AMI events from 2002 and onwards. 
Incident events could thus only be defined for the years 2001 through 2009 because patients with an AMI before 2001 did not have a 7 year look-back period to search for previous events. Incident AMI hospitalizations according to the 7-year rule are given in Table 4. The observed overall percentage of known recurrent events classified as incident events is $4.2 \%$, but the true percentage is probably closer to the percentage in $2009,7.5 \%$. The percentage is only $0.6 \%$ in 2001 , but the 12797 events classified as events with no previous AMI-hospitalizations are probably a mixture of true first-time AMIs and recurrent AMIs where the first event happened before 1994 and thus not included in CVDNOR. If we only include events in the first column of Table 4 as incident AMI hospitalizations we will introduce a bias in the time trend since we will have a mixture of first-time AMIs and recurrent AMIs the first years and almost 100\% pure first-time AMIs in 2009, since we have 15 years of lookback-time available for events in 2009. Using only the first column would be equivalent to using an increasing sized look-back window to look for previous events, 7 years in 2001 and 15 years in 2009.

Table 4: Incident AMI hospitalizations in Norway 2001-2009, according to the 7 year rule. The CVDNOR project.

\begin{tabular}{|l|l|r|r|}
\hline Year & $\begin{array}{l}\text { Incident AMI } \\
\text { hospitalizations with no } \\
\text { AMI-hospitalizations the } \\
\text { previous 7 years }\end{array}$ & $\begin{array}{l}\text { Incident AMI } \\
\text { hospitalizations with } \\
\text { previous AMI- } \\
\text { hospitalization >7 years } \\
\text { ago }\end{array}$ & $\begin{array}{l}\text { Total Incident AMI } \\
\text { hospitalizations }\end{array}$ \\
\hline $\mathbf{2 0 0 1}$ & 12797 & $75(0.6 \%)$ & 12872 \\
\hline $\mathbf{2 0 0 2}$ & 12994 & $221(1.7 \%)$ & 13215 \\
\hline $\mathbf{2 0 0 3}$ & 13115 & $376(2.8 \%)$ & 13491 \\
\hline $\mathbf{2 0 0 4}$ & 12204 & $436(3.5 \%)$ & 12640 \\
\hline $\mathbf{2 0 0 5}$ & 12128 & $545(4.3 \%)$ & 12673 \\
\hline $\mathbf{2 0 0 6}$ & 12058 & $655(5.2 \%)$ & 12713 \\
\hline $\mathbf{2 0 0 7}$ & 11874 & $757(6.0 \%)$ & 12631 \\
\hline $\mathbf{2 0 0 8}$ & 12454 & $841(6.3 \%)$ & 13295 \\
\hline $\mathbf{2 0 0 9}$ & 12483 & $1018(7.5 \%)$ & 13501 \\
\hline $\mathbf{2 0 0 1 - 2 0 0 9}$ & $\mathbf{1 1 2 1 0 7}$ & $\mathbf{4 9 2 4}(\mathbf{4 . 2} \%)$ & $\mathbf{1 1 7 0 3 1}$ \\
\hline
\end{tabular}

The number of incident AMIs per year will be overestimated by maximum 7\% by using the 7-year censoring rule, but the time-trends will be preserved and unbiased. The two bottom lines in Figure 1 show the difference between using the 7 -year rule and by using all available years to look for previous events. The gap between the two lines is increasing because the bottom line includes a mixture of recurrent events and fist-time events the first years, but not the last years. 


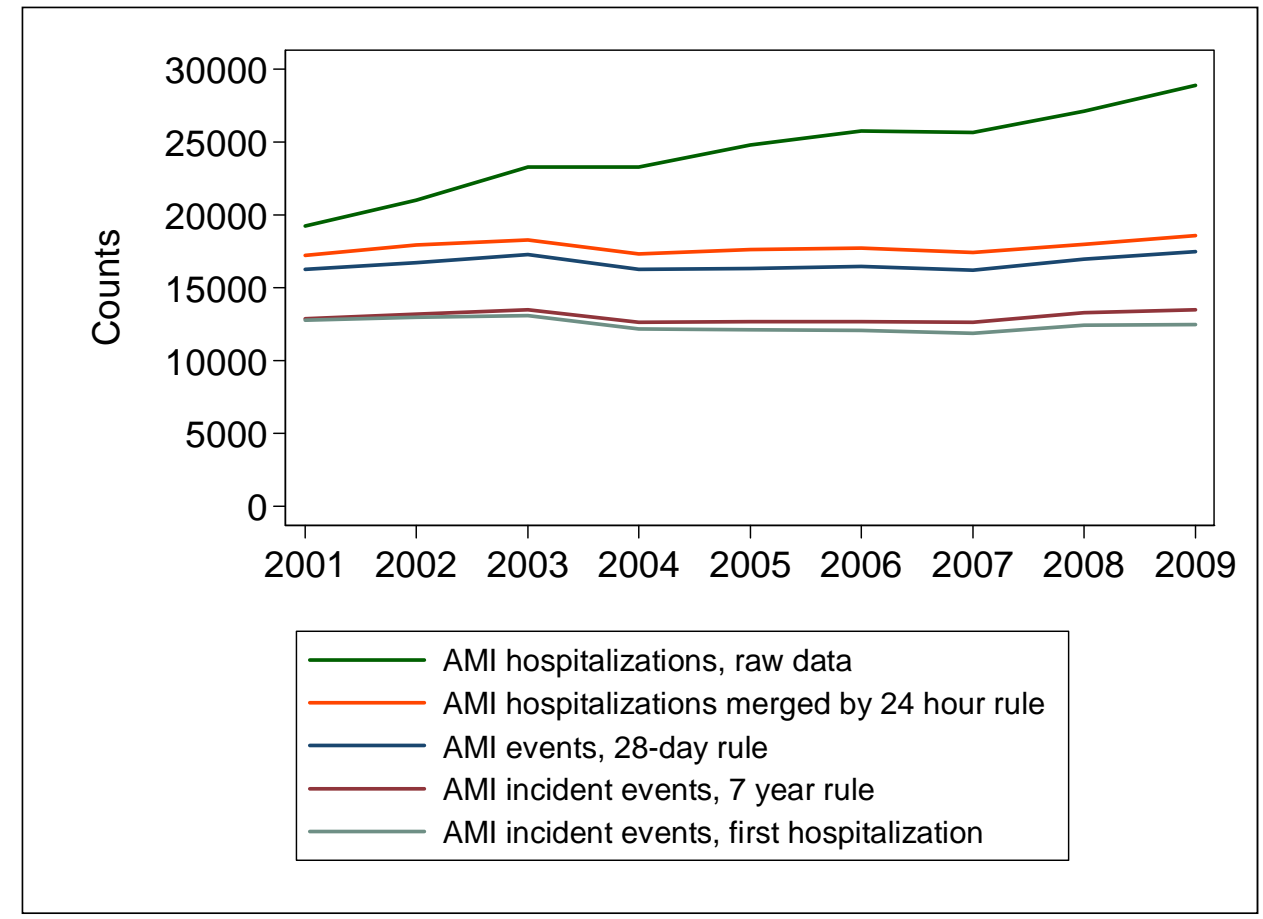

Figure 1: AMI-hospitalizations, AMI-events and incident AMI-events by calendar year 


\section{Overview of hospitalizations (FS-Data)}

Table 5: Overview of hospitalizations, 1994-2009. The CVDNOR project.

\begin{tabular}{lrrr}
\hline & Men & Women & Total \\
\hline Patients, $\mathbf{n}$ (\%) & $640325(48.7)$ & $674692(51.3)$ & 1315057 \\
\hline Age, mean (SD) & $64.0(19.0)$ & $66.0(21.3)$ & $64.9(20.2)$ \\
\hline Count of hospitalizations*, $\mathbf{n}(\%)$ & & & \\
\hline Hospitalizations in total & $2270535(53.2)$ & $1996173(46.8)$ & 4266751 \\
\hline CVD hospitalizations & $1677554(54.1)$ & $1421295(45.9)$ & 3098849 \\
\hline CHD hospitalizations & $750031(61.1)$ & $477909(38.9)$ & 1227940 \\
\hline UAP hospitalizations & $60212(63.3)$ & $34877(36.7)$ & 95089 \\
\hline AMI hospitalizations & $157230(61.3)$ & $99272(38.7)$ & 256502 \\
\hline ACS hospitalizations & $205154(61.5)$ & $128718(38.6)$ & 333872 \\
\hline CEREBRO hospitalizations & $259102(52.8)$ & $231591(47.2)$ & 490693 \\
\hline TOTS hospitalizations & $152473(51.6)$ & $142991(48.4)$ & 295464 \\
\hline AA hospitalizations & $51878(72.4)$ & $19736(27.6)$ & 71614 \\
\hline HT hospitalizations & $452223(48.0)$ & $490446(52.0)$ & 942669 \\
\hline HF hospitalizations & $252522(51.6)$ & $237376(48.5)$ & 489898 \\
\hline AF hospitalizations & $346490(55.0)$ & $282955(45.0)$ & 629445 \\
\hline DM hospitalizations & $340537(53.4)$ & $297208(46.6)$ & 637745 \\
\hline PRECL hospitalizations & & $49359(100)$ & 49359 \\
\hline CongHeart hospitalizations & 27054 & 25985 & 53039 \\
\hline Hospitalizations with PCI & $59781(74.7)$ & $20291(25.3)$ & 80072 \\
\hline Hospitalizations with CABG & $34013(76.4)$ & $10495(23.6)$ & 44508 \\
\hline Hospitalizations with VECAT & $115405(67.9)$ & $54589(32.1)$ & 169994 \\
\hline Hospitalizations with HVECAT & $121328(68.1)$ & $56840(31.9)$ & 178168 \\
\hline
\end{tabular}

* Hospitalizations less than 24 hours apart are merged before counting. All counts are hospitalizations with the given disease/procedure are main or secondary diagnosis. 
Hospitalization-data linked with demographic data and the Cause of Death Registry

Table 6: Death by underlying cause of death. Hospitalized patients were followed until 31Dec2010.

\begin{tabular}{lccr}
\hline & Men & Women & Total \\
\hline Patients, $\mathbf{n}$ & 640325 & 674692 & 1315057 \\
\hline Deaths among patients hospitalized 1994-2009 & & & \\
All-cause deaths & 234867 & 237637 & 472504 \\
\hline CVD deaths & 104607 & 111584 & 216191 \\
\hline Cancer deaths & 59434 & 48146 & 107580 \\
\hline Diabetes deaths & 4583 & 4974 & 9557 \\
\hline Deaths from other diseases & 50900 & 56704 & 107604 \\
\hline Accidents and violent deaths & 9157 & 8540 & 17697 \\
\hline Deaths among persons not hospitalized 1994-2009 & & & 1933 \\
\hline CVD deaths & 31374 & 37613 & 68987 \\
\hline Diabetes deaths & 859 & 1074 & \\
\hline
\end{tabular}

The high number of CVD deaths among persons not hospitalized in CVDNOR between 1994 and 2009 demonstrates the need for inclusion of deaths outside hospital when we want to estimate incidence rates for different subgroups of cardiovascular disease. 
Table 7: Sociodemographic data at first hospitalization between 1994 and 2009, only including patients >30 years at first hospitalization and with match in the Population Registry.

\begin{tabular}{|c|c|c|c|}
\hline & Men & Women & Total \\
\hline Patients & 570428 & 585171 & 1155599 \\
\hline Age at first hospitalization, mean (SD) & $64.0(14.9)$ & 66.7 (16.9) & $65.3(16.0)$ \\
\hline \multicolumn{4}{|l|}{ Marital status, $\mathbf{n}$ (\% within gender) } \\
\hline Married & $369111(64.7)$ & $263507(45.0)$ & $632618(54.7)$ \\
\hline Widow(er) & $52897(9.3)$ & $191791(32.8)$ & $244688(21.2)$ \\
\hline Divorced/separated & $66502(11.7)$ & 64949 (11.1) & $131451(11.4)$ \\
\hline Unmarried & 78987 (13.9) & $62636(10.7)$ & $141623(12.2)$ \\
\hline Unspecified & $2931(0.5)$ & $2288(0.4)$ & $5219(0.5)$ \\
\hline \multicolumn{4}{|l|}{$\begin{array}{l}\text { Residence by NUTS2-Region* } \\
\text {, n(\% within gender) }\end{array}$} \\
\hline Oslo/Akershus & $108333(19.0)$ & $117945(20.2)$ & 226228 (19.6) \\
\hline Hedmark/Oppland & 53206 (9.3) & $52499(9.0)$ & $105705(9.2)$ \\
\hline Sør- $\varnothing$ stlandet & $117953(20.7)$ & 122035 (20.9) & $239988(20.8)$ \\
\hline Agder/Rogaland & 74434 (13.1) & $73002(12.5)$ & $147436(12.8)$ \\
\hline Vestlandet & $100853(17.7)$ & $105445(18.0)$ & 206298 (17.9) \\
\hline Trøndelag & $49327(8.7)$ & $49330(8.4)$ & $98657(8.5)$ \\
\hline Nord-Norge & 63382 (11.1) & 62621 (10.7) & 126003 (10.9) \\
\hline Unspecified & $2940(0.5)$ & $2294(0.4)$ & $5234(0.5)$ \\
\hline \multicolumn{4}{|l|}{ Highest completed education, $n(\%)$} \\
\hline Basic education or less & $210063(36.8)$ & $271051(46.3)$ & 481114 (41.6) \\
\hline Upper secondary education (Videregående) & $254005(44.5)$ & $220243(37.6)$ & 474248 (41.0) \\
\hline Tertiary education, short (up to 4 years) & $60663(10.6)$ & $67832(11.6)$ & $128495(11.1)$ \\
\hline Tertiary education, long (more than 4 years) & $29644(5.2)$ & $10070(1.7)$ & $39714(3.4)$ \\
\hline Unspecified & $16053(2.8)$ & $15975(2.7)$ & $32028(2.8)$ \\
\hline Median income in 1000 NOK (q20-q25) & $219(146-315)$ & $135(95-212)$ & $174(112-265)$ \\
\hline \multicolumn{4}{|l|}{ Country of birth, $n(\%)$} \\
\hline Norway & 540853 (94.8) & 553666 (94.6) & 1094519 (94.7) \\
\hline Other Nordic countries & 7502 (1.3) & $8083(1.4)$ & 15585 (1.4) \\
\hline Other European countries & $9958(1.8)$ & 9933 (1.7) & $19891(1.7)$ \\
\hline Countries outside Europe & $12053(2.1)$ & $13406(2.3)$ & $25459(2.2)$ \\
\hline Unspecified & $62(0.0)$ & $83(0.0)$ & $145(0.0)$ \\
\hline \multicolumn{4}{|l|}{ Country of origin } \\
\hline Norway & $531856(93.2)$ & $545471(93.2)$ & $1077327(93.2)$ \\
\hline Other Nordic countries & $11672(2.1)$ & $11853(2.0)$ & $23525(2.0)$ \\
\hline Other European countries & $12095(2.1)$ & $12075(2.1)$ & $24170(2.1)$ \\
\hline Countries outside Europe & $14743(2.6)$ & $15689(2.7)$ & $30432(2.6)$ \\
\hline Unspecified & $62(0.0)$ & $83(0.0)$ & $145(0.0)$ \\
\hline
\end{tabular}

*NUTS= Nomenclature of Territorial Units for Statistics. Standard for geographical regions defined by Eurostat (http://epp.eurostat.ec.europa.eu/portal/page/portal/nuts nomenclature/introduction) 


\section{Data quality, hospital data}

\section{Invalid personal identification numbers}

Among the 1,3 million patients with at least one hospitalization with a qualifying diagnosis or procedure code, 28357 (2,2\%) did not match with the demographic data from the Population Registry, probably because of invalid personal identification number. $32 \%$ of these patients where registered with age 0 at the time of hospitalizations and are probably newborns. Most of the remaining patients are probably foreigners/tourists without a permanent address in Norway. These patients should be excluded from calculation of incidence rates since we don't know if the patient could be present several times in the data with different personal identification numbers (valid or invalid). They should also be excluded from follow-up analyses since we are not able to link them to the Cause of Death Registry or to any other data sources.

\section{Missing or wrong year of birth/age}

36 patients had missing age or age less than 0 or above 110 at the time of hospitalization. After exclusion of patients with no demographic data match, this number was reduced to 23 . Of these, 5 patients were not registered with a valid birth year in the demographic data, while for the other 18 the wrong age was caused by a 100-year difference between the year of birth registered in the hospital data and the year of birth registered in the Population Registry.

\section{Missing and invalid municipality codes in hospital data}

Among the 4,7 million hospitalizations fulfilling the inclusion criteria in CVDNOR, 16637 (0.4\%) did not have a valid municipality code registered for the patient in the patient administrative system. Of the 16637 hospitalizations, only 3220 had a valid personal identification number for the patient which made it possible to link to the demographic data from the Population Registry. When linking to the Population Registry a valid municipality code was found for $51 \%$ of the 3220 .

\section{Overlapping hospitalizations}

Among the 4,7 million hospitalizations fulfilling the inclusion criteria in CVDNOR, 123294 (2.6\%) had an overlap in time with at least one other hospitalization. Among the hospitalizations with overlap, $17.9 \%$ had an overlapping hospitalization at the same hospital while $82.1 \%$ had an overlapping hospitalization at a different hospital. 


\section{Hospitalizations close in time}

A total of 660989 hospitalizations (14.1\% of all hospitalizations) occurred <24 hours after another hospitalization for the same patient. An overview of re-hospitalizations is given in Table 8. About $57 \%$ of re-hospitalizations within 24 hours occurred at a new hospital while $43 \%$ occurred at the same hospital. When counting hospitalizations for different disease group we corrected for rehospitalizations as described on page 9 .

Table 8: Count of hospitalizations occurring close in time for the same patient

\begin{tabular}{|c|c|c|}
\hline Type of re-hospitalization & $\mathbf{n}$ & $\begin{array}{c}\% \text { of total } \\
\text { hospitalizations } \\
\text { in CVDNOR }\end{array}$ \\
\hline $\begin{array}{l}\text { New hospitalization at the same hospital } \leq 10 \text { minutes } \\
\text { after previous hospitalization ended. }\end{array}$ & 16267 & 0.4 \\
\hline $\begin{array}{l}\text { New hospitalization at different hospital } \leq 10 \text { minutes } \\
\text { after previous hospitalization ended. }\end{array}$ & 13879 & 0.3 \\
\hline $\begin{array}{l}\text { New hospitalization at the same hospital 11-60 } \\
\text { minutes after previous hospitalization ended. }\end{array}$ & 35520 & 0.8 \\
\hline $\begin{array}{l}\text { New hospitalization at different hospital 11-60 } \\
\text { minutes after previous hospitalization ended. }\end{array}$ & 95129 & 2.0 \\
\hline $\begin{array}{l}\text { New hospitalization at the same hospital 1-8 hours } \\
\text { after previous hospitalization ended. }\end{array}$ & 65557 & 1.4 \\
\hline $\begin{array}{l}\text { New hospitalization at different hospital 1-8 hours } \\
\text { after previous hospitalization ended. }\end{array}$ & 250006 & 5.3 \\
\hline $\begin{array}{l}\text { New hospitalization at the same hospital 8-24 hours } \\
\text { after previous hospitalization ended. }\end{array}$ & 167539 & 3.6 \\
\hline $\begin{array}{l}\text { New hospitalization at different hospital 8-24 hours } \\
\text { after previous hospitalization ended. }\end{array}$ & 17092 & 0.4 \\
\hline $\begin{array}{l}\text { Total number of hospitalizations with re- } \\
\text { hospitalization within } 24 \text { hours }\end{array}$ & 660989 & 14.1 \\
\hline $\begin{array}{l}\text { Total number of hospitalizations in CVDNOR 1994- } \\
2009\end{array}$ & $\begin{array}{r}4686 \\
072\end{array}$ & \\
\hline
\end{tabular}

\section{Missing hospitalization dates}

Only 37 hospitalizations had missing hospitalization dates.

\section{Stays at technical wards}

Some patients had one or more short stays at a technical ward during their hospitalization. These short stays where stored as separates data rows in the database. In some cases procedure codes and diagnosis codes were mentioned at the technical post without being mentioned at any other wardstays during the hospitalization. In order to avoid any loss of information, 11 diagnosis codes and 20 procedure codes from technical wards during a hospitalization where added as extra variables to each hospitalization record. In most cases this was only a repetition of codes that where already present. 


\section{Quality of Cause of Death Data}

472504 of the 1.3 million patients with a qualifying diagnosis or procedure code during 1994-2009 had died by the end of 2010. Of these patients, 515 had at least one hospitalizations registered in CVDNOR after the date of death registered in the Cause of Death registry, indicating that either the date of death or the date of hospitalization must be wrong. Out of 515 cases 121 (23.5\%) had a different date of death registered in the Population Registry than in the Cause of Death Registry The date in the Population Registry was larger or equal to the last hospitalization date. This suggests that the date of death registered in the Cause of Death Registry is wrong. The remaining 394 cases had the same date of death in both registries, which might indicate that the hospitalization date is wrong.

\section{Comparison with data from the Western Norway Cardiovascular Registry (HKS-registeret)}

An earlier research project on cardiovascular disease in Western Norway, the Western Norway Cardiovascular Registry (HKS-registeret) ${ }^{6-8}$, have complete data on Cardiovascular hospitalizations in Health Region West from 1992-2006. The extraction of hospitalization data in this project was done manually by IT-employees at each hospital without using the FS-system. We did a comparison of the count of patients in different disease groups between CVDNOR-data and data from HKS for the years between 1994 and 2006. In general the deviation between counts of patients in CVDNOR and HKS was small. The results for the disease groups AMI, CEREBRO and DM are given in Table 9, Table 10 and Table 11.

Table 9: Number of unique persons with acute myocardial infarction (AMI) as main or secondary diagnosis in CVDNOR and the Western Norway Cardiovascular Registry (HKS)

\begin{tabular}{|r|r|r|r|r|}
\hline & CVDNOR* & HKS & $\begin{array}{l}\text { Absolute } \\
\text { deviation }\end{array}$ & $\begin{array}{l}\text { Deviation in \% } \\
\text { of CVDNOR-count }\end{array}$ \\
\hline $\mathbf{1 9 9 4}$ & 2578 & 2578 & 0 & 0.00 \\
\hline $\mathbf{1 9 9 5}$ & 2676 & 2675 & 1 & 0.04 \\
\hline $\mathbf{1 9 9 6}$ & 2463 & 2465 & -2 & -0.08 \\
\hline $\mathbf{1 9 9 7}$ & 2362 & 2364 & -2 & -0.08 \\
\hline $\mathbf{1 9 9 8}$ & 2444 & 2438 & 6 & 0.25 \\
\hline $\mathbf{1 9 9 9}$ & 2412 & 2412 & 0 & 0.00 \\
\hline $\mathbf{2 0 0 0}$ & 2406 & 2406 & 0 & 0.00 \\
\hline $\mathbf{2 0 0 1}$ & 2687 & 2686 & 1 & 0.04 \\
\hline $\mathbf{2 0 0 2}$ & 2989 & 2989 & 0 & 0.00 \\
\hline $\mathbf{2 0 0 3}$ & 3123 & 3124 & -1 & -0.03 \\
\hline $\mathbf{2 0 0 4}$ & 3175 & 3160 & 15 & 0.47 \\
\hline $\mathbf{2 0 0 5}$ & 3178 & 3157 & 21 & 0.66 \\
\hline $\mathbf{2 0 0 6}$ & 3133 & 3101 & 32 & 1.02 \\
\hline
\end{tabular}

* Hospitals in Health Region West only. See Appendix C. 
Table 10: Number of unique persons with cerebrovascular disease (CEREBRO) as main or secondary diagnosis in CVDNOR and the Western Norway Cardiovascular Registry

\begin{tabular}{|r|r|r|r|r|}
\hline & CVDNOR* & HKS & $\begin{array}{l}\text { Absolute } \\
\text { deviation }\end{array}$ & $\begin{array}{l}\text { Deviation in \% } \\
\text { of CVDNOR-count }\end{array}$ \\
\hline $\mathbf{1 9 9 4}$ & 3291 & 3282 & 9 & 0.27 \\
\hline $\mathbf{1 9 9 5}$ & 3400 & 3392 & 8 & 0.24 \\
\hline $\mathbf{1 9 9 6}$ & 3547 & 3548 & -1 & -0.03 \\
\hline $\mathbf{1 9 9 7}$ & 3545 & 3542 & 3 & 0.08 \\
\hline $\mathbf{1 9 9 8}$ & 3859 & 3853 & 6 & 0.16 \\
\hline $\mathbf{1 9 9 9}$ & 3378 & 3384 & -6 & -0.18 \\
\hline $\mathbf{2 0 0 0}$ & 3457 & 3458 & -1 & -0.03 \\
\hline $\mathbf{2 0 0 1}$ & 3622 & 3621 & 1 & 0.03 \\
\hline $\mathbf{2 0 0 2}$ & 3655 & 3655 & 0 & 0.00 \\
\hline $\mathbf{2 0 0 3}$ & 3854 & 3860 & -6 & -0.16 \\
\hline $\mathbf{2 0 0 4}$ & 3924 & 3923 & 1 & 0.03 \\
\hline $\mathbf{2 0 0 5}$ & 4061 & 4054 & 7 & 0.17 \\
\hline $\mathbf{2 0 0 6}$ & 4051 & 4052 & -1 & -0.02 \\
\hline
\end{tabular}

* Hospitals in Health Region West only. See Appendix C

Table 11: Number of unique persons with diabetes mellitus (DM) as main or secondary diagnosis in CVDNOR and the Western Norway Cardiovascular Registry

\begin{tabular}{|r|r|r|r|r|}
\hline & CVDNOR & HKS & $\begin{array}{l}\text { Absolute } \\
\text { deviation }\end{array}$ & $\begin{array}{l}\text { Deviation in \% } \\
\text { of CVDNOR-count }\end{array}$ \\
\hline $\mathbf{1 9 9 4}$ & 3018 & 3011 & 7 & 0.23 \\
\hline $\mathbf{1 9 9 5}$ & 3084 & 3083 & 1 & 0.03 \\
\hline $\mathbf{1 9 9 6}$ & 3096 & 3099 & -3 & -0.10 \\
\hline $\mathbf{1 9 9 7}$ & 3206 & 3209 & -3 & -0.09 \\
\hline $\mathbf{1 9 9 8}$ & 3757 & 3759 & -2 & -0.05 \\
\hline $\mathbf{1 9 9 9}$ & 3676 & 3706 & -30 & -0.82 \\
\hline $\mathbf{2 0 0 0}$ & 4117 & 4129 & -12 & -0.29 \\
\hline $\mathbf{2 0 0 1}$ & 4484 & 4485 & -1 & -0.02 \\
\hline $\mathbf{2 0 0 2}$ & 4665 & 4677 & -12 & -0.26 \\
\hline $\mathbf{2 0 0 3}$ & 5314 & 5318 & -4 & -0.08 \\
\hline $\mathbf{2 0 0 4}$ & 5694 & 5695 & -1 & -0.02 \\
\hline $\mathbf{2 0 0 5}$ & 6075 & 6067 & 8 & 0.13 \\
\hline $\mathbf{2 0 0 6}$ & 6369 & 6363 & 6 & 0.09 \\
\hline
\end{tabular}

* Hospitals in Health Region West only. See Appendix C 


\section{Count of hospitalizations by main diagnosis}

In the following chapter count of hospitalizations with main diagnosis in different disease groups are given per calendar year both by hospital and for all hospitals in total. Hospitalizations occurring 24 hours or less apart for the same patient are merged and counted as one.

In graphs showing number of hospitalizations per hospital, hospitalizations within 24 hours are merged only if there is more than one hospitalization within 24 hours at the same hospital. If a patient has two hospitalizations within 24 hours at two different hospitals it counts as one hospitalization in each hospital.

The graphs with number of hospitalizations per hospital have been smoothed with median splines. The hospital-numbers are given at the top of each graph. A table with the full hospital name for each hospital number is given in appendix C. Hospitals with less than 5 hospitalizations per year for a given disease group has been left out of the graphs. 


\section{Number of hospitalizations in Norway by main diagnosis}
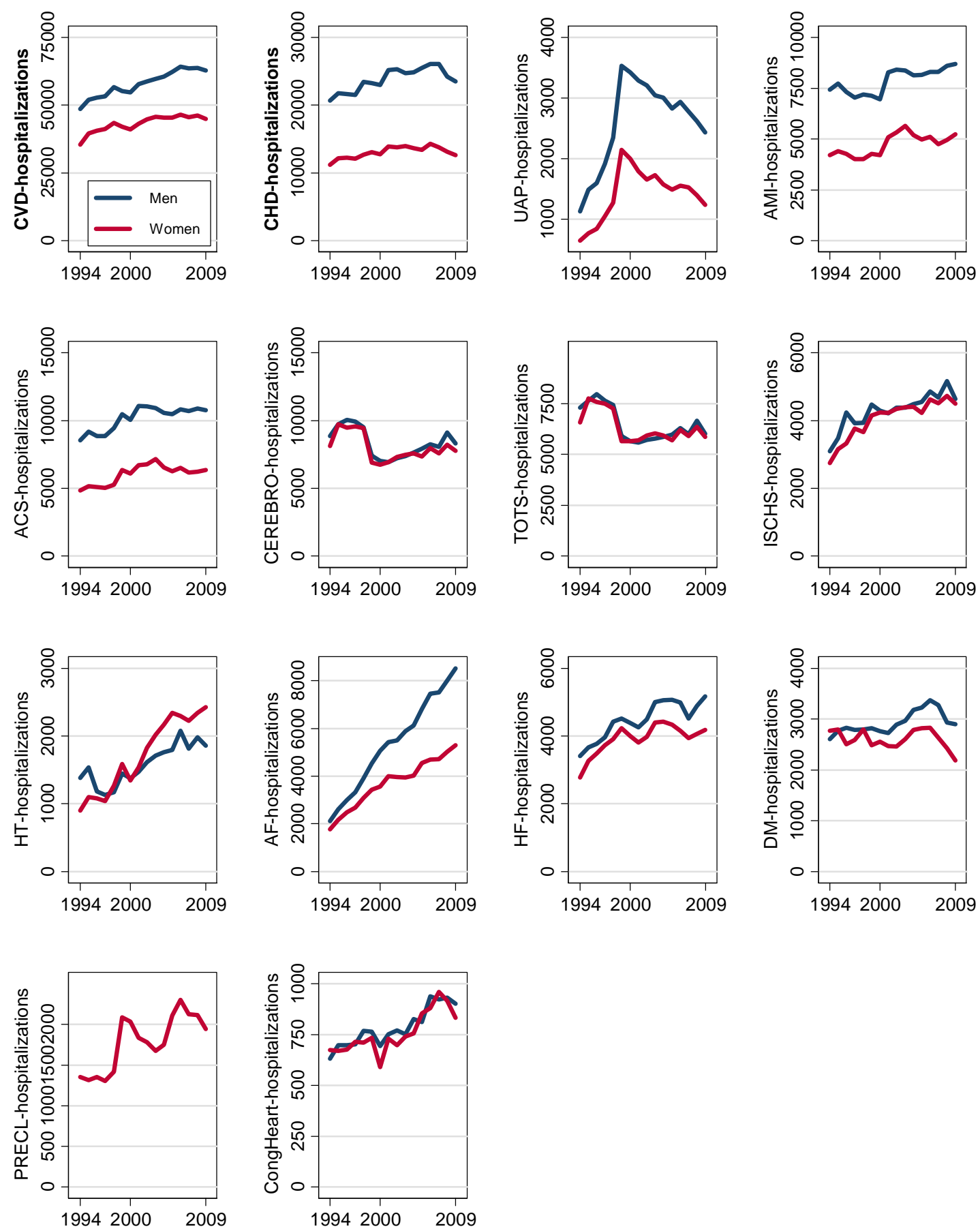

Figure 2: Total number of hospitalizations in Norway by main diagnosis. Hospitalizations in the same hospital occurring $\leq \mathbf{2 4}$ hours apart have been merged before counting. 
Hospitalizations with cardiovascular disease (CVD) as main diagnosis by hospital
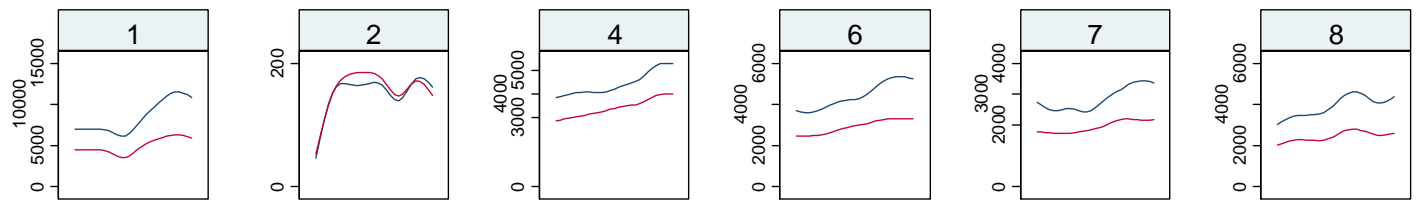

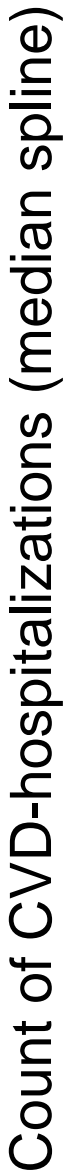
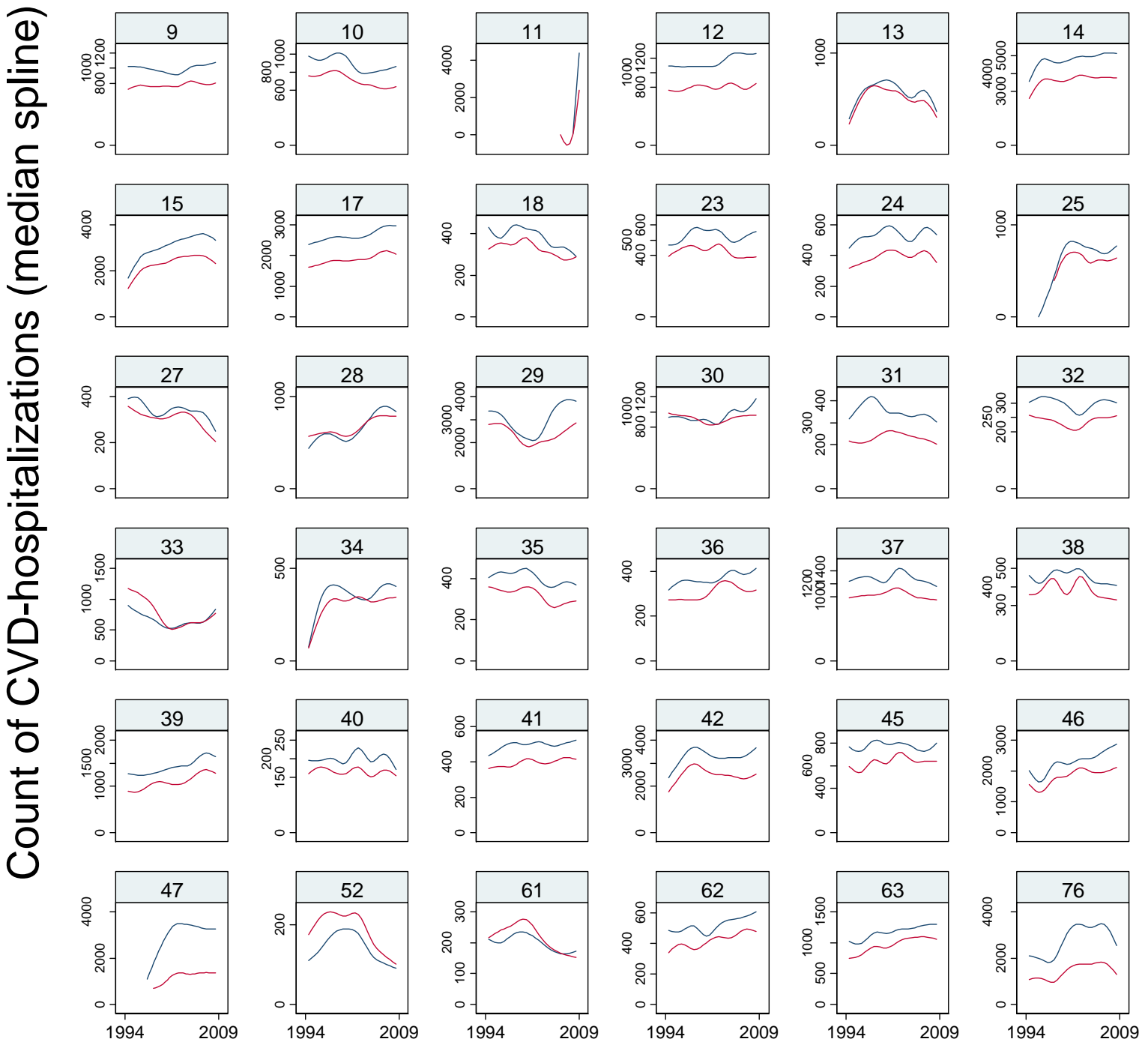

Year

Men

Women

Figure 3: Count of hospitalizations with CVD as main diagnosis by hospital, 1994-2009 
Hospitalizations with coronary heart disease (CHD) as main diagnosis by hospital
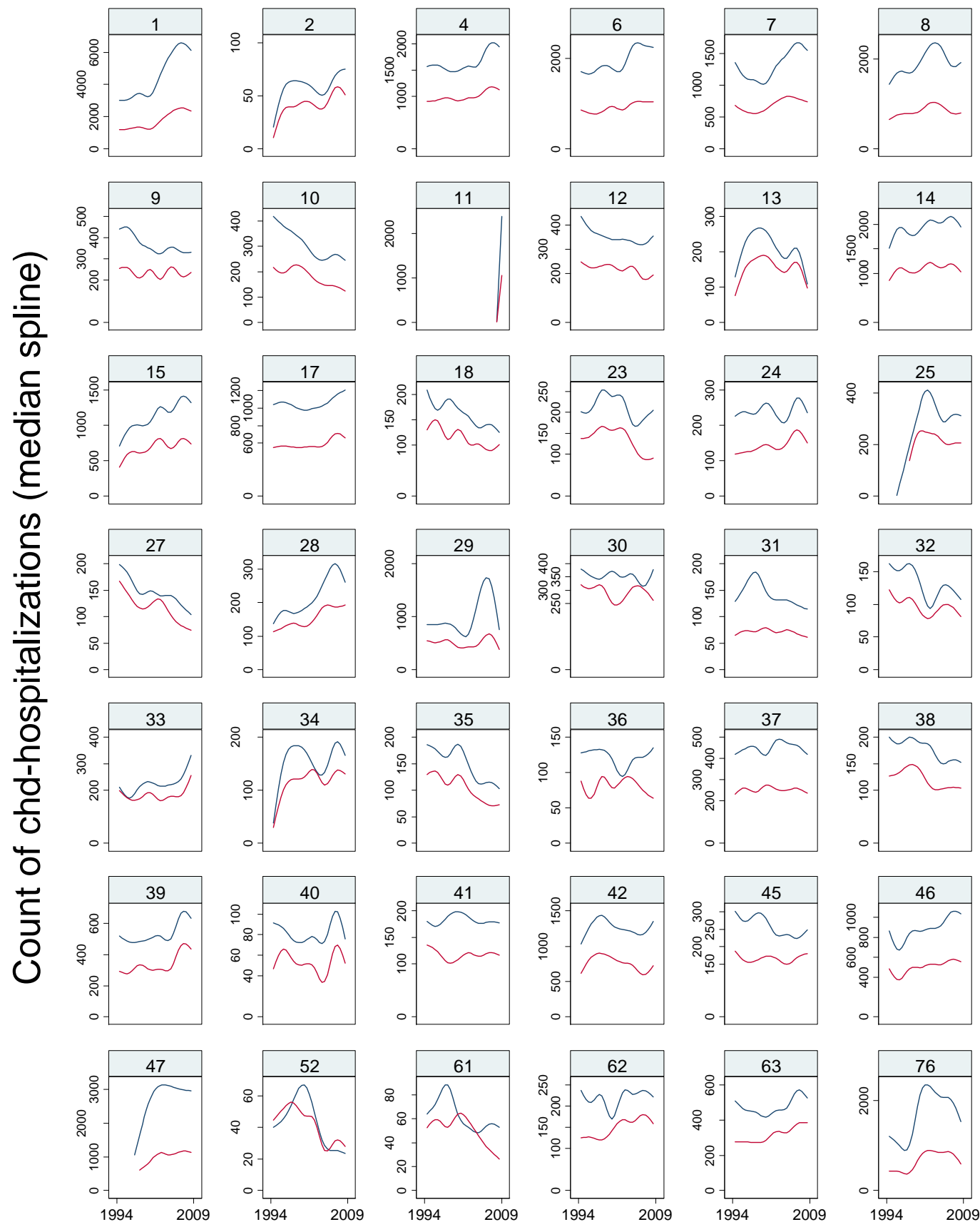

Year

Men

Women

Figure 4: Count of hospitalizations with CHD as main diagnosis by hospital, 1994-2009 
Hospitalizations with acute myocardial infarction (AMI) as main diagnosis by hospital
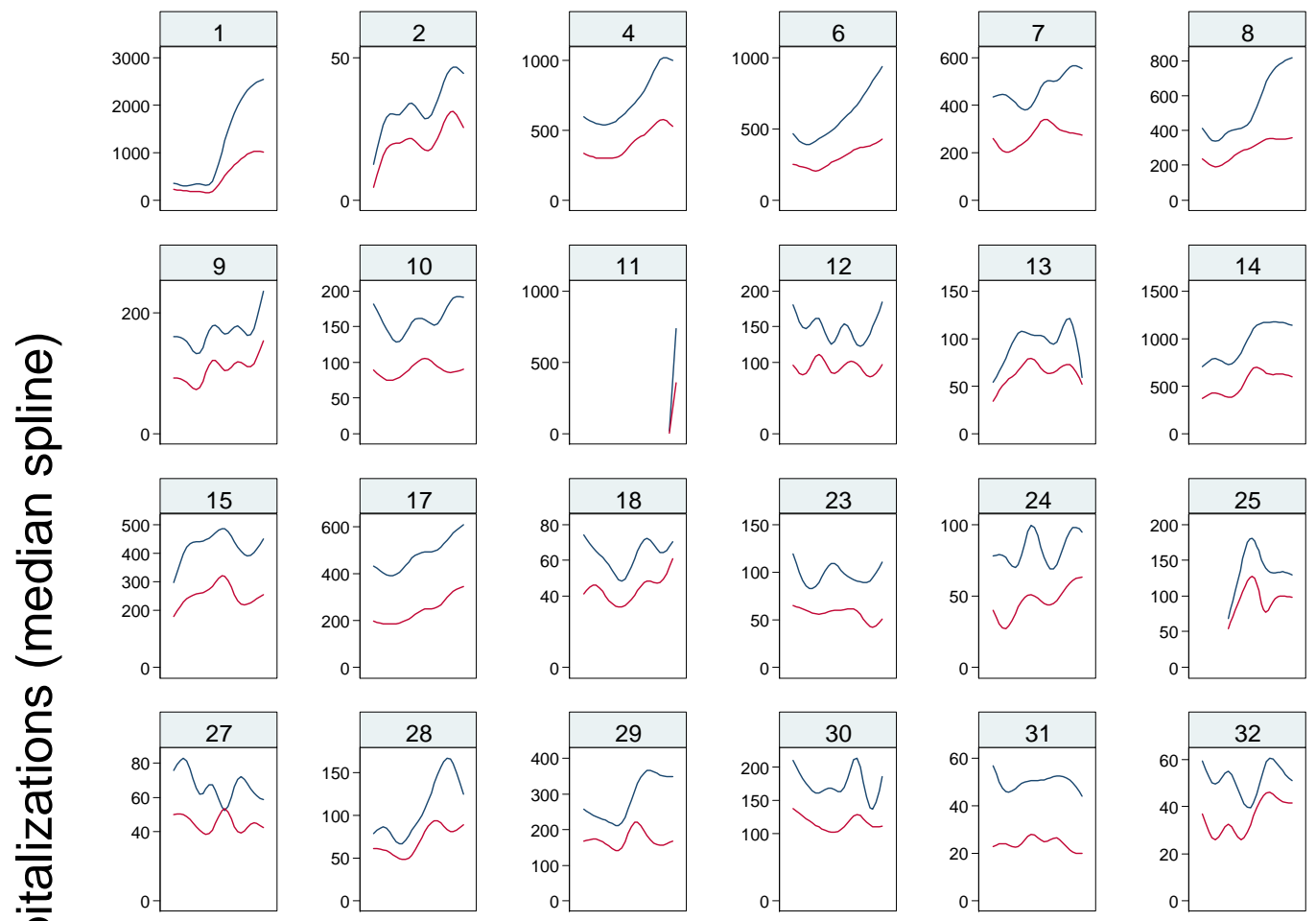

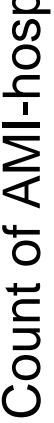
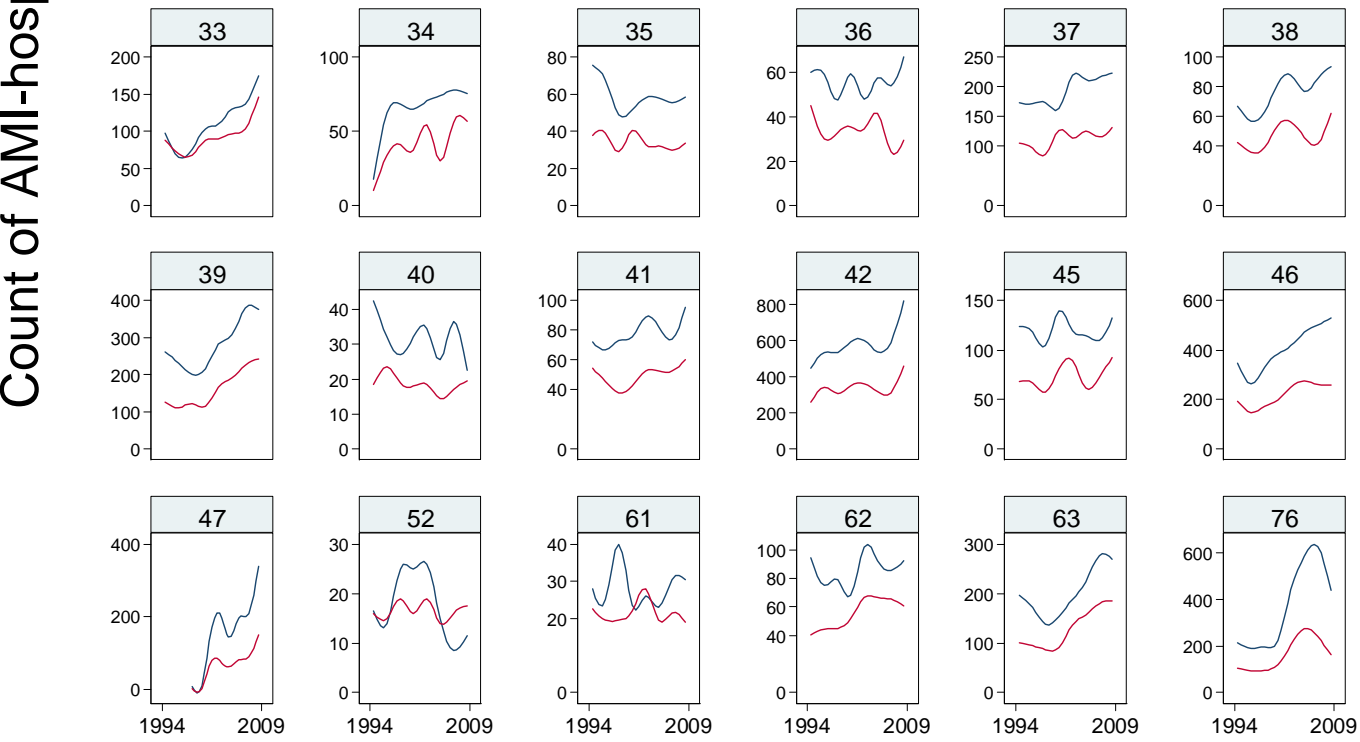

Year 
Hospitalizations with unstable angina pectoris (UAP) as main diagnosis by hospital

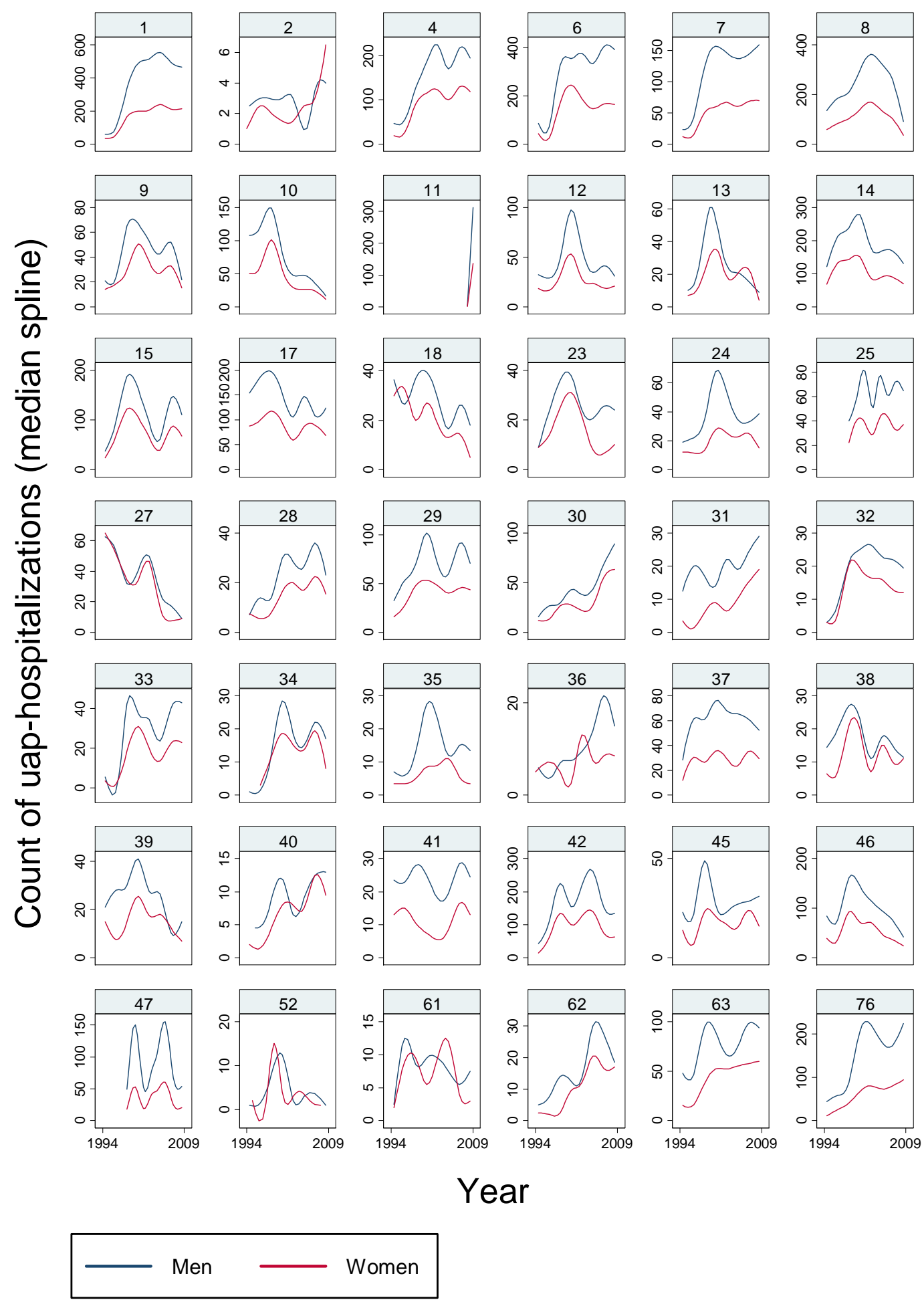

Figure 6: Count of hospitalizations with UAP as main diagnosis by hospital, 1994-2009 


\section{Hospitalizations with acute coronary syndrome (ACS) as main diagnosis by}

hospital
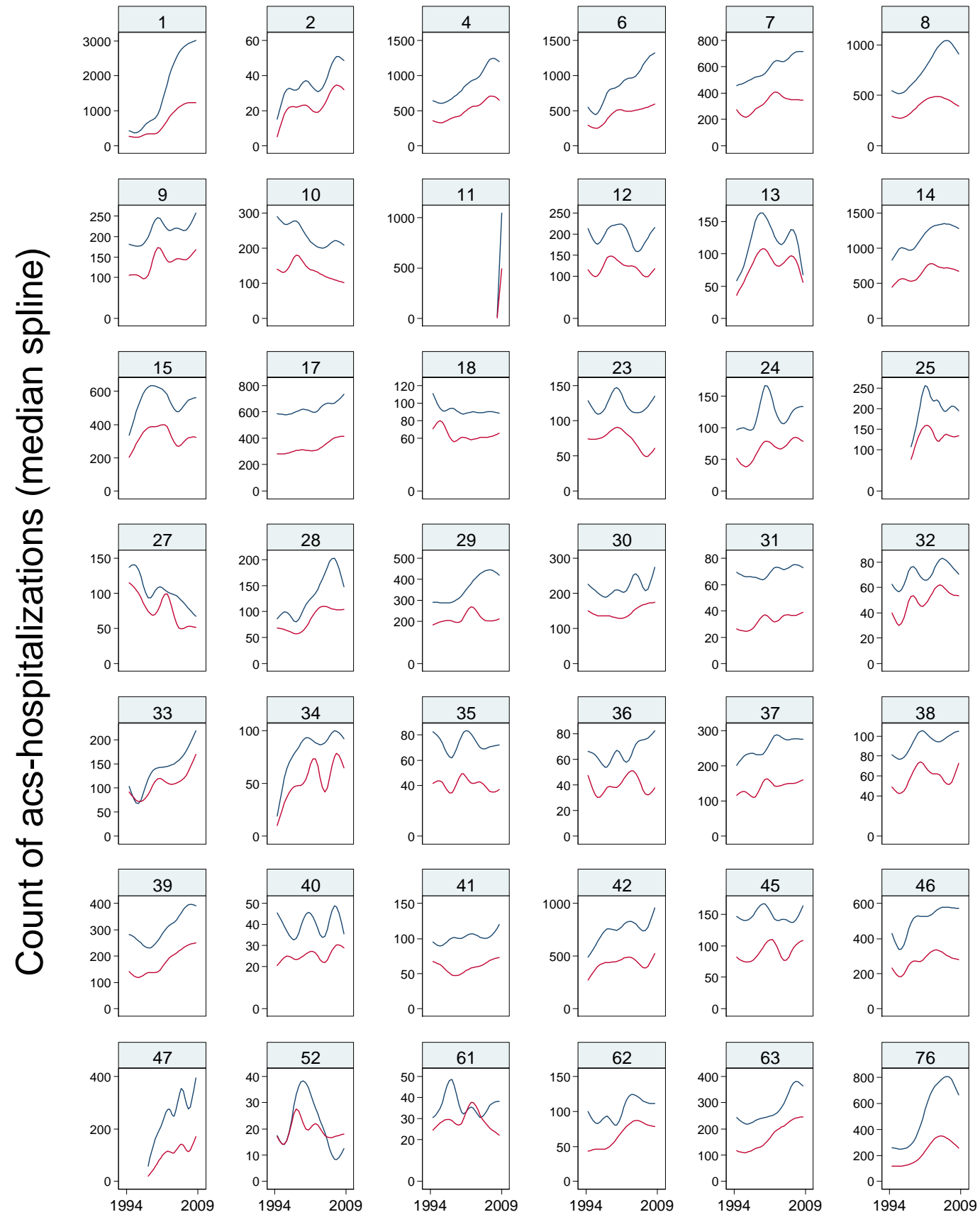

Year

Men

Women

Figure 7: Count of hospitalizations with ACS as main diagnosis by hospital, 1994-2009 


\section{Hospitalizations with cerebrovascular disease (CEREBRO) as main}

diagnosis by hospital
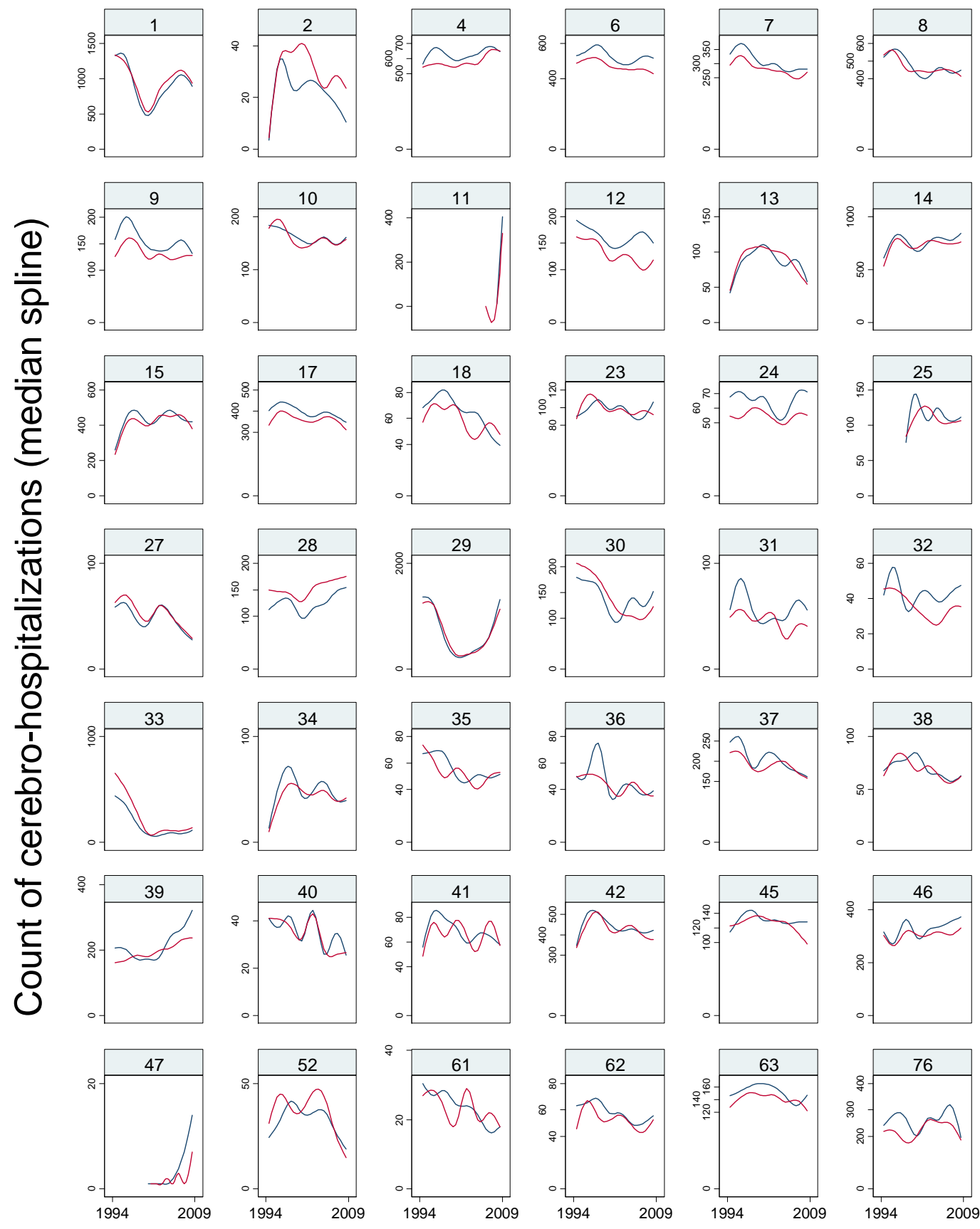

Year

Men

Women

Figure 8: Count of hospitalizations with CEREBRO as main diagnosis by hospital, 1994-2009 


\section{Hospitalizations with ischemic stroke (ISCHS ) as main diagnosis by hospital}
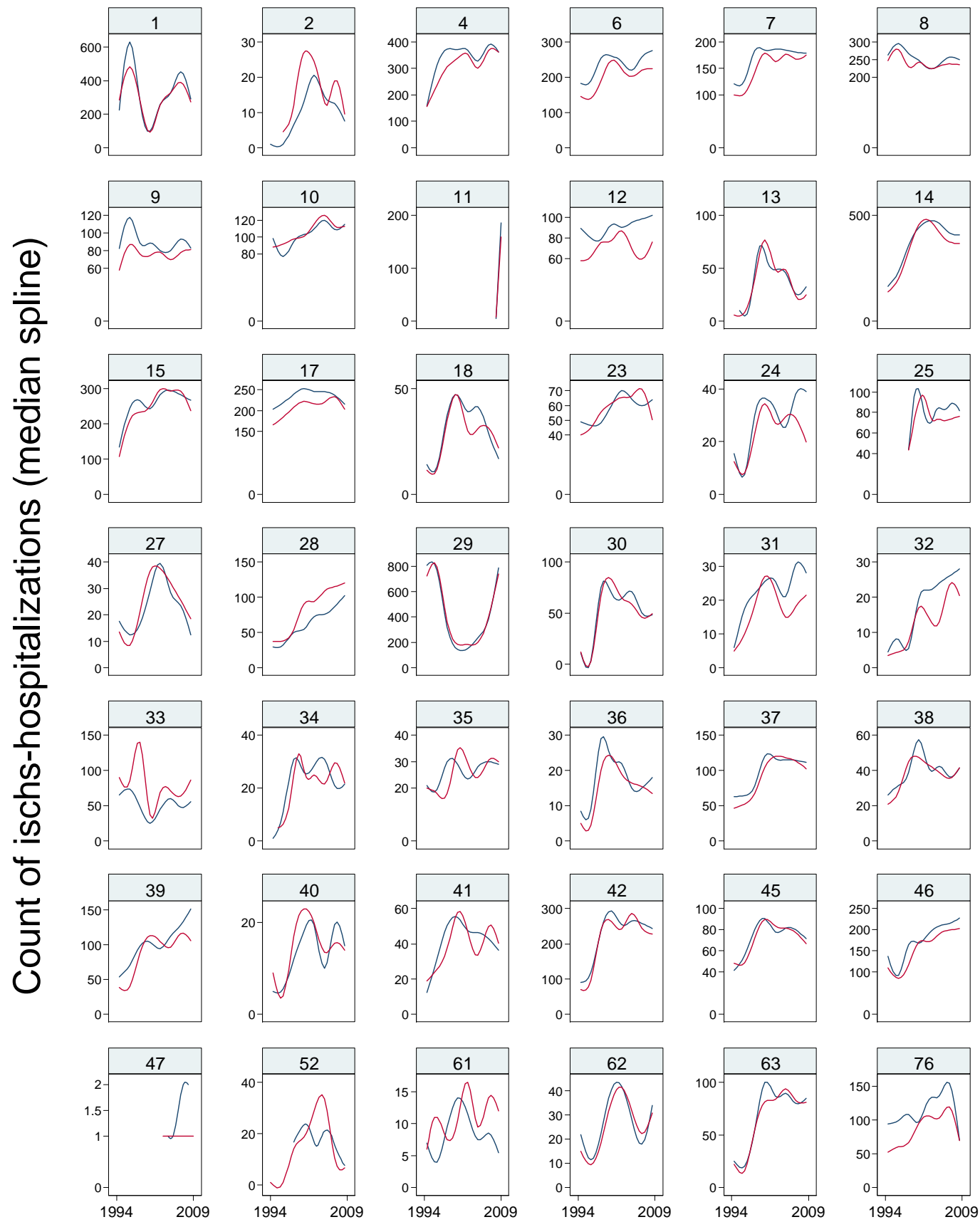

Year

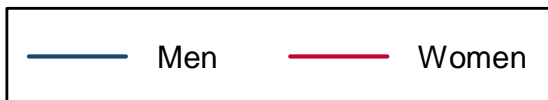

Figure 9: Count of hospitalizations with ISCHS as main diagnosis by hospital, 1994-2009 
Hospitalizations with total stroke (TOTS) as main diagnosis by hospital
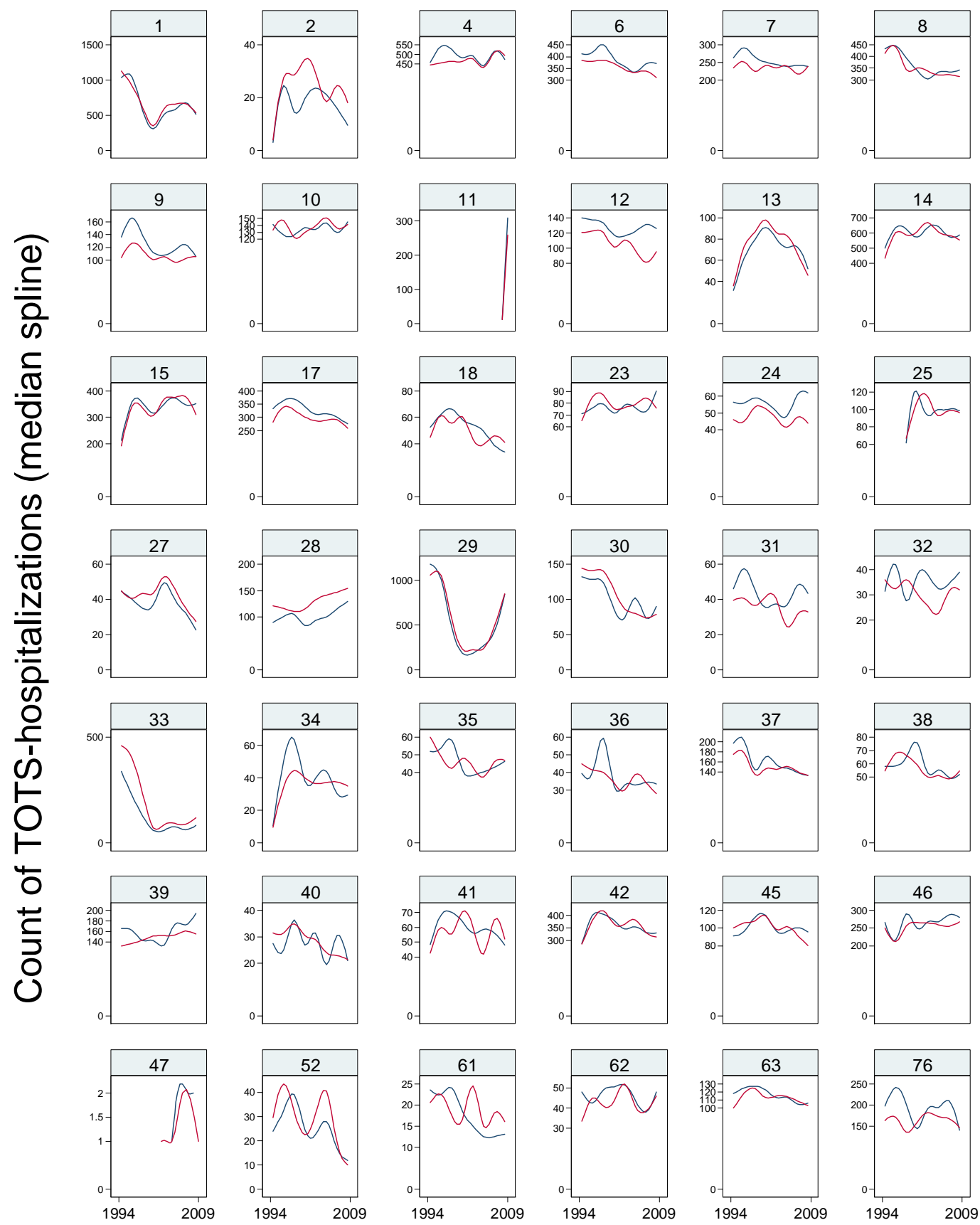

Year

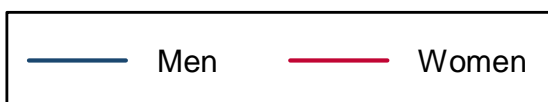

Figure 10: Count of hospitalizations with TOTS as main diagnosis by hospital, 1994-2009 


\section{Hospitalizations with diabetes (DM) as main diagnosis by hospital}
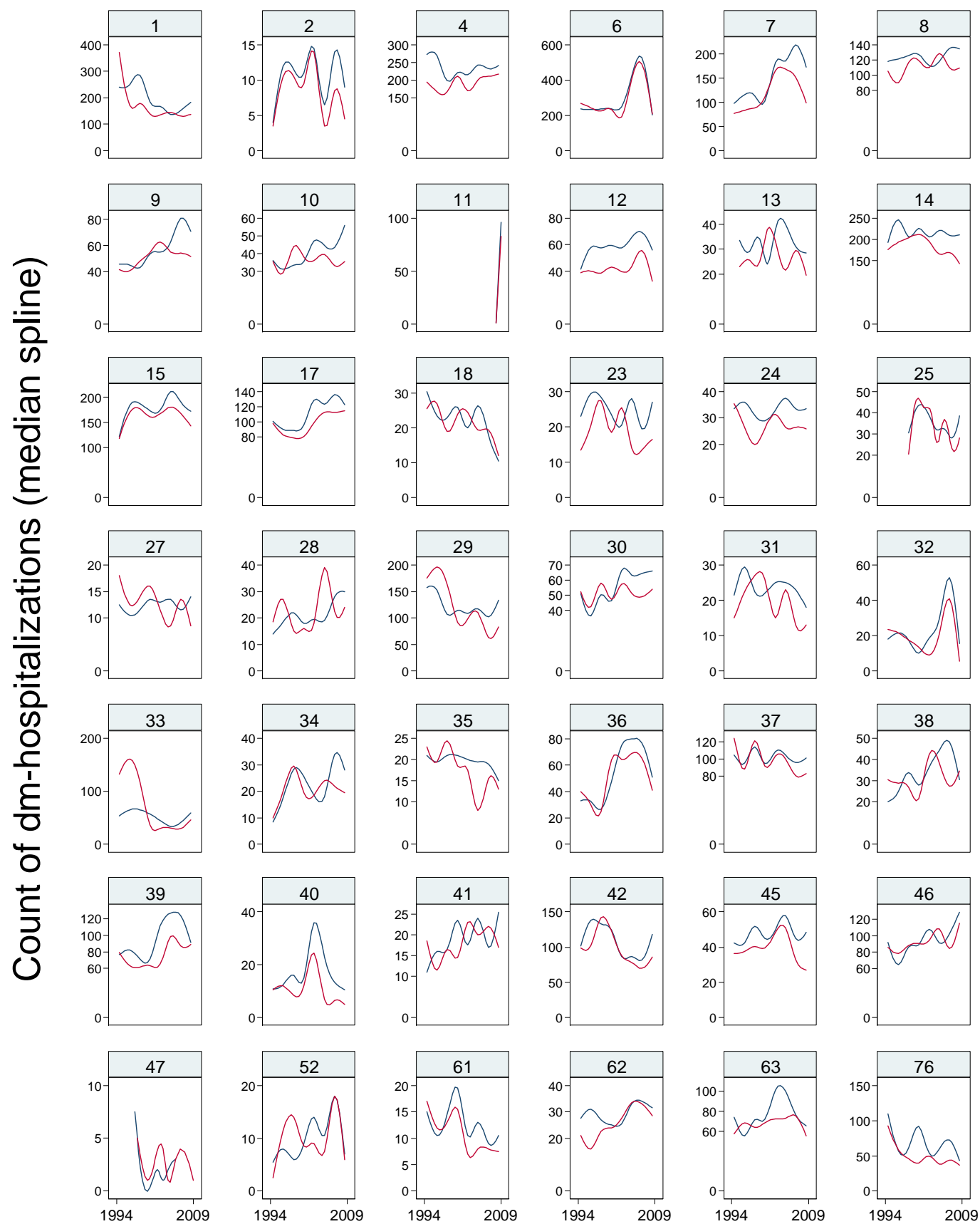

Year

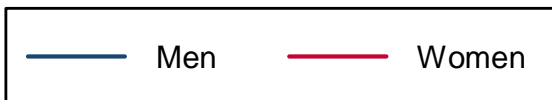

Figure 11: Count of hospitalizations with DM as main diagnosis by hospital, 1994-2009 


\section{Hospitalizations with atrial fibrillation (AF) as main diagnosis by hospital}
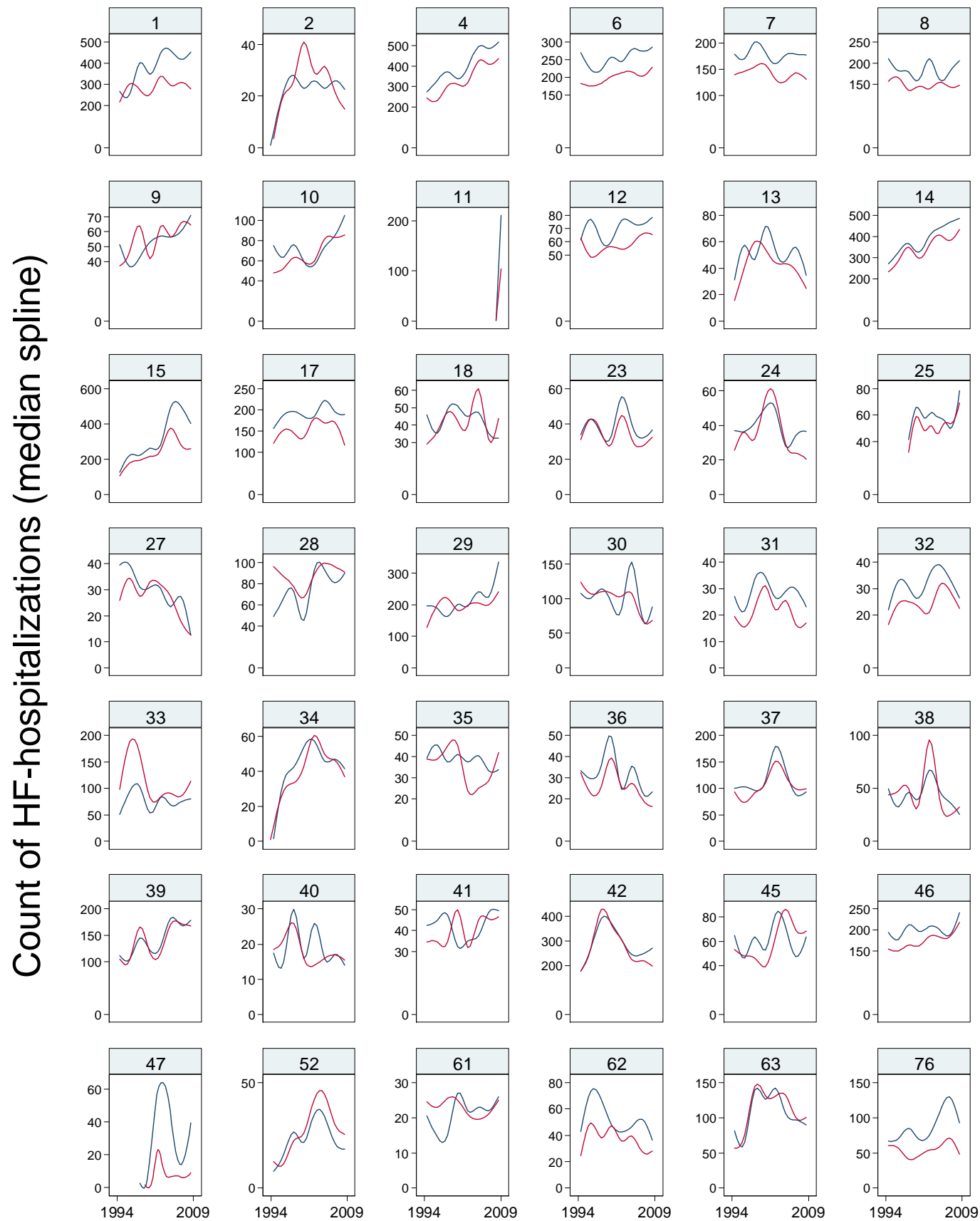

Year

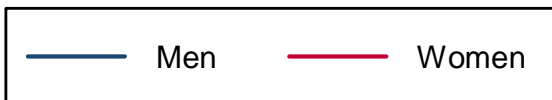

Figure 12: Count of hospitalizations with AF as main diagnosis by hospital, 1994-2009 


\section{Hospitalizations with hypertension (HT) as main diagnosis by hospital}
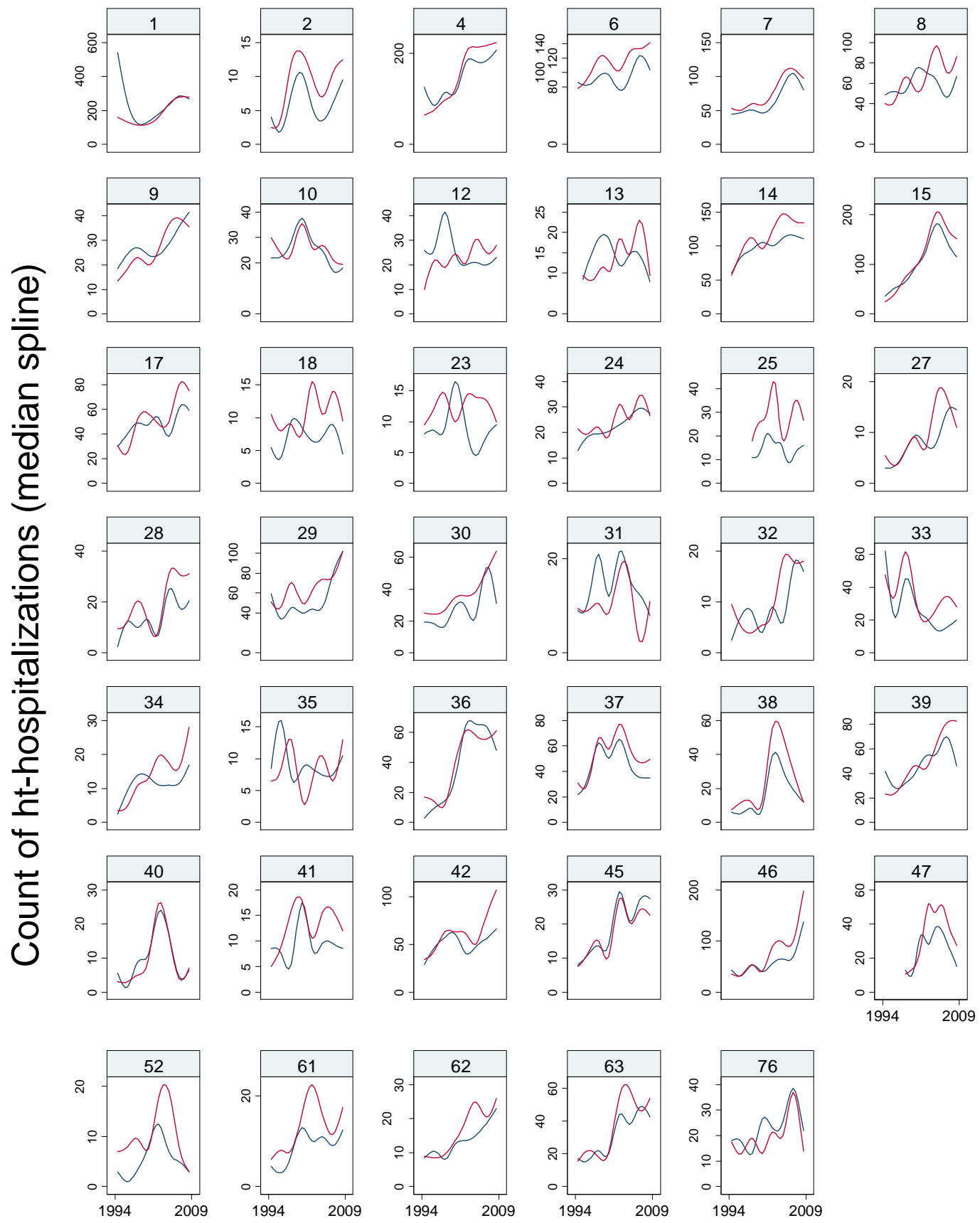

Year

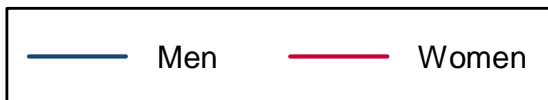

Figure 13: Count of hospitalizations with HT as main diagnosis by hospital, 1994-2009 


\section{Hospitalizations with heart failure (HF) as main diagnosis by hospital}
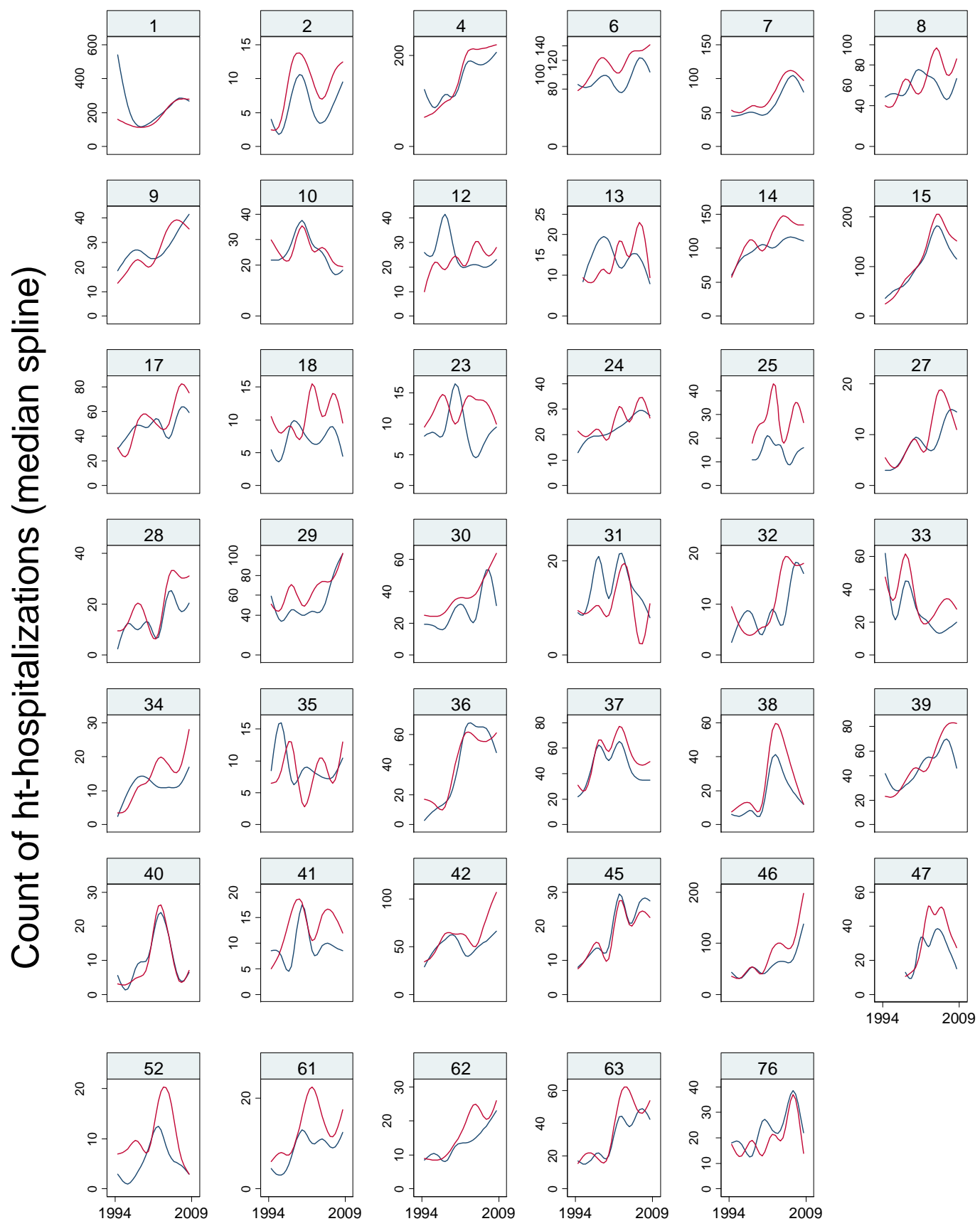

Year

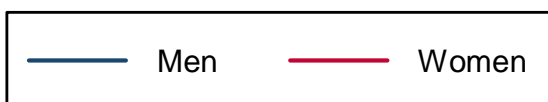

Figure 14: Count of hospitalizations with HF as main diagnosis by hospital, 1994-2009 


\section{Hospitalizations with pre-eclampsia or eclampsia (PRECL) as main}

diagnosis by hospital

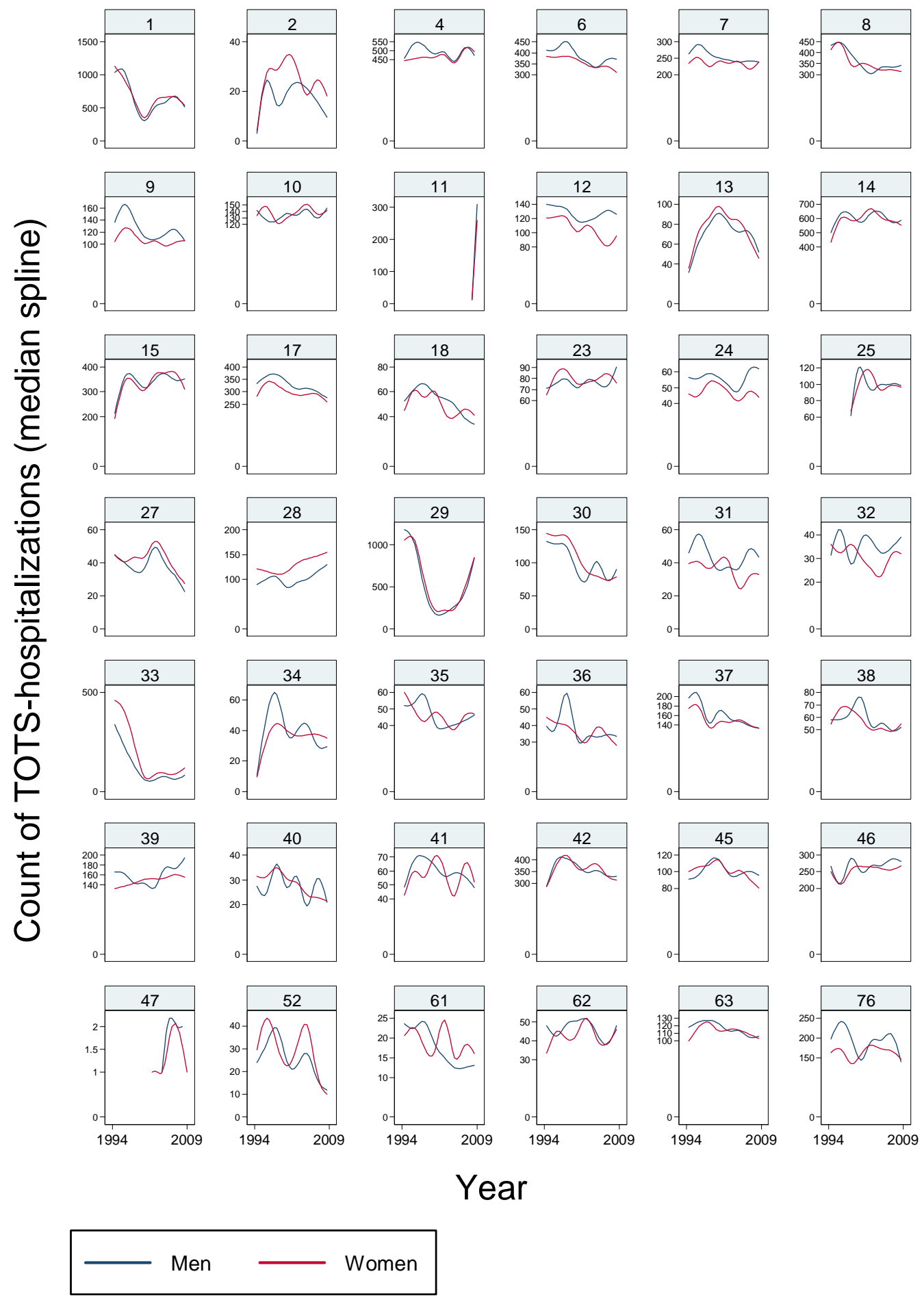

Figure 15: Count of hospitalizations with PRECL as main diagnosis by hospital, 1994-2009 
Hospitalizations with congenital heart defect (CongHeart) as main diagnosis by hospital
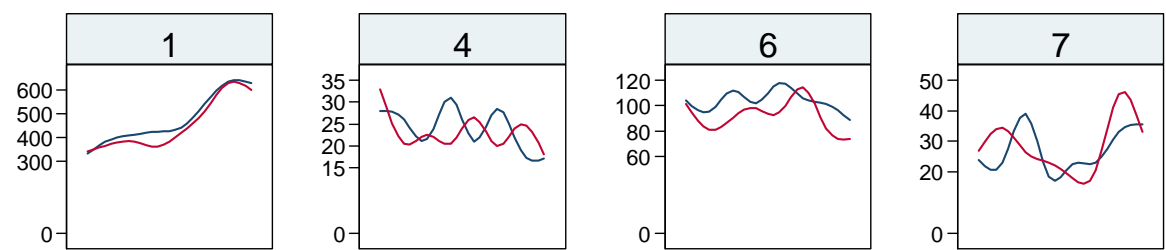

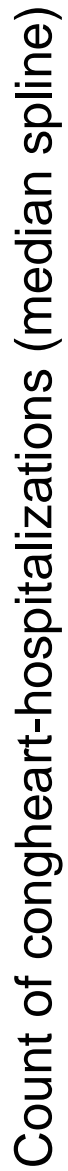
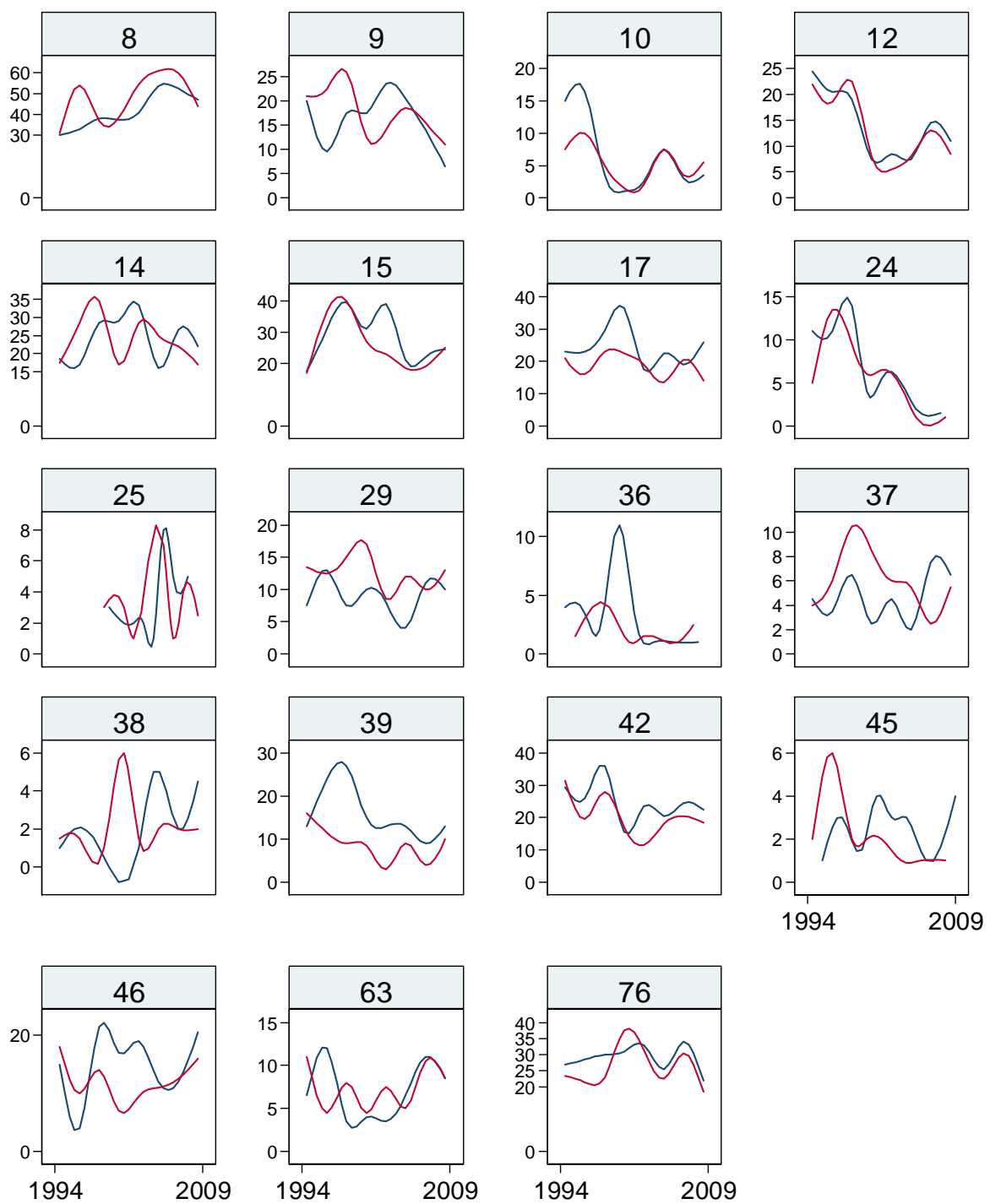

Year 
Count of hospitalizations by procedure groups

Count of total number of hospitalizations in Norway by procedure groups
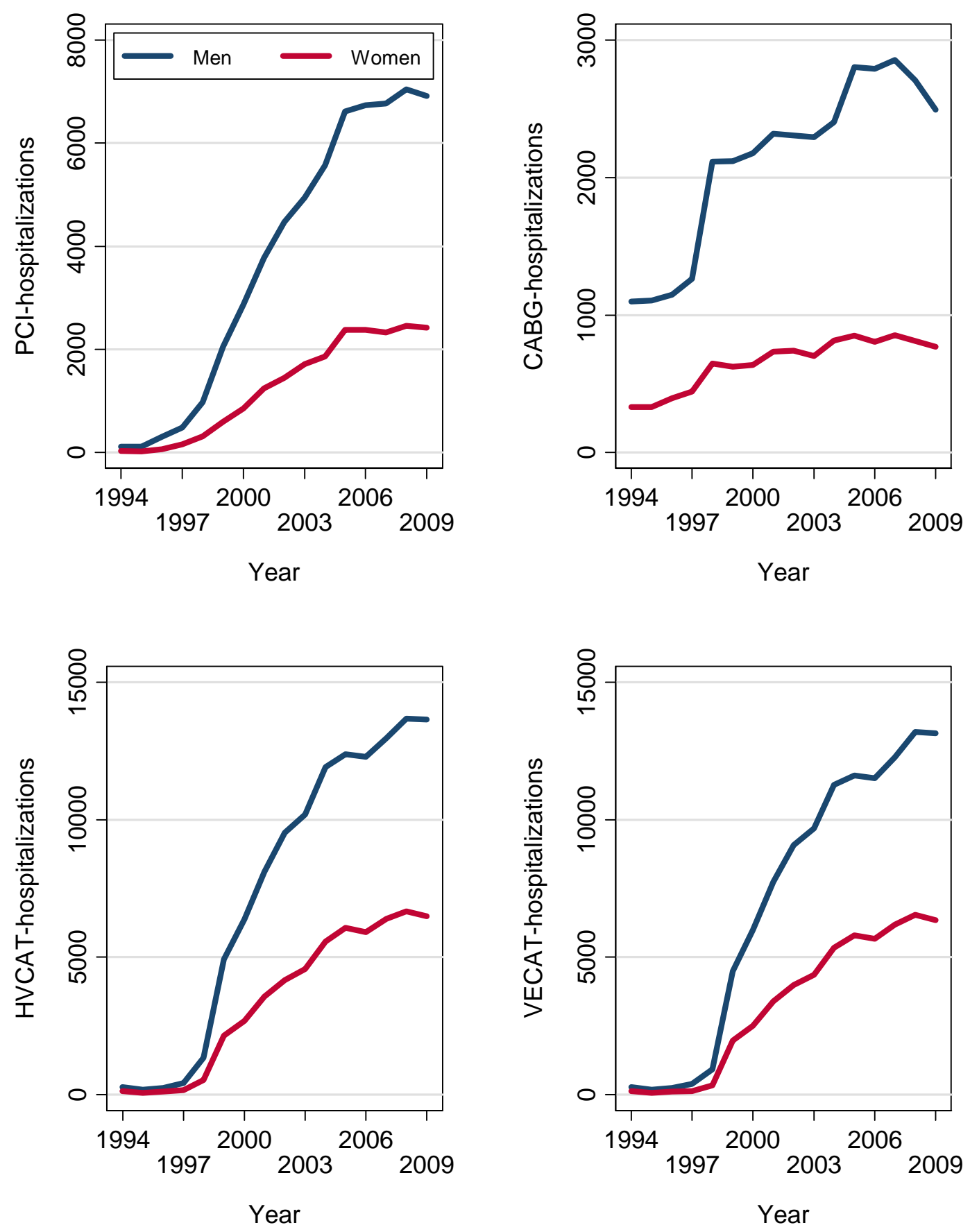

Figure 17: Count of hospitalizations by procedure group, total numbers for Norway 
Hospitalizations with PCI by hospital

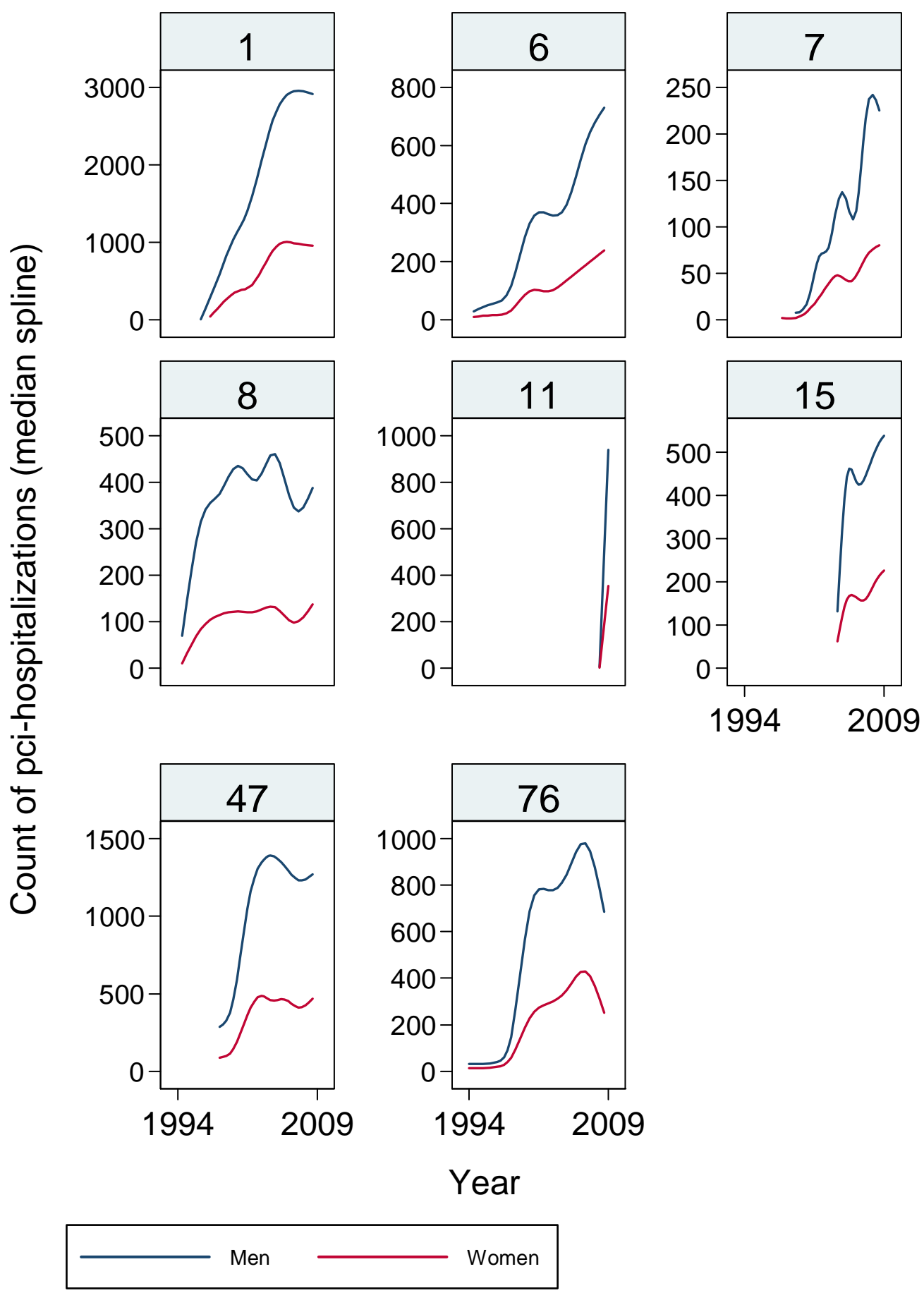

Figure 18: Count of hospitalizations with $\mathrm{PCl}$ (percutaneous coronary intervention) as main diagnosis by hospital, 1994-2009 
Hospitalizations with CABG by hospital

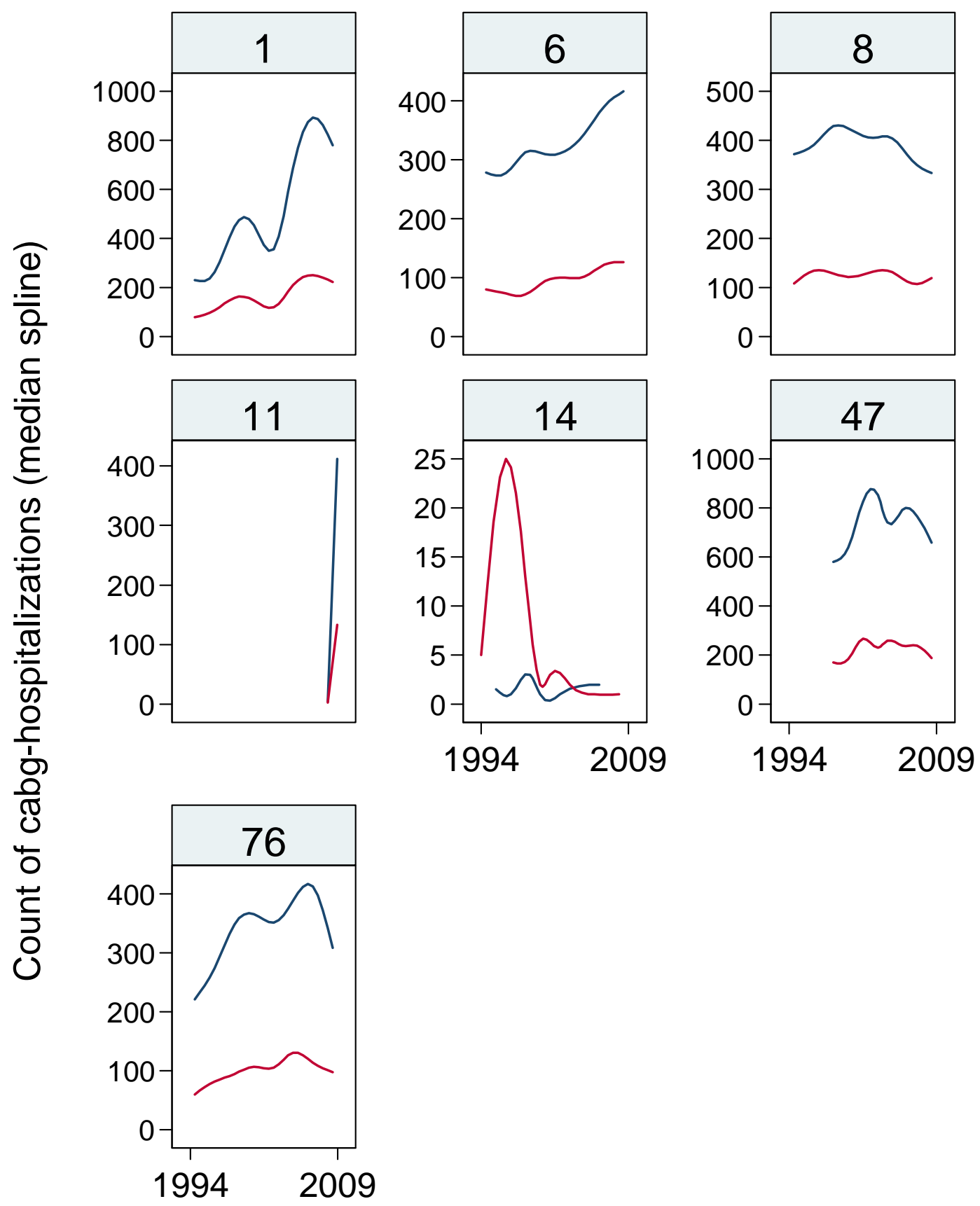

Year

Figure 19: Count of hospitalizations with CABG (coronary artery bypass graft) as main diagnosis by hospital, 1994-2009 
Hospitalizations with VECAT by hospital

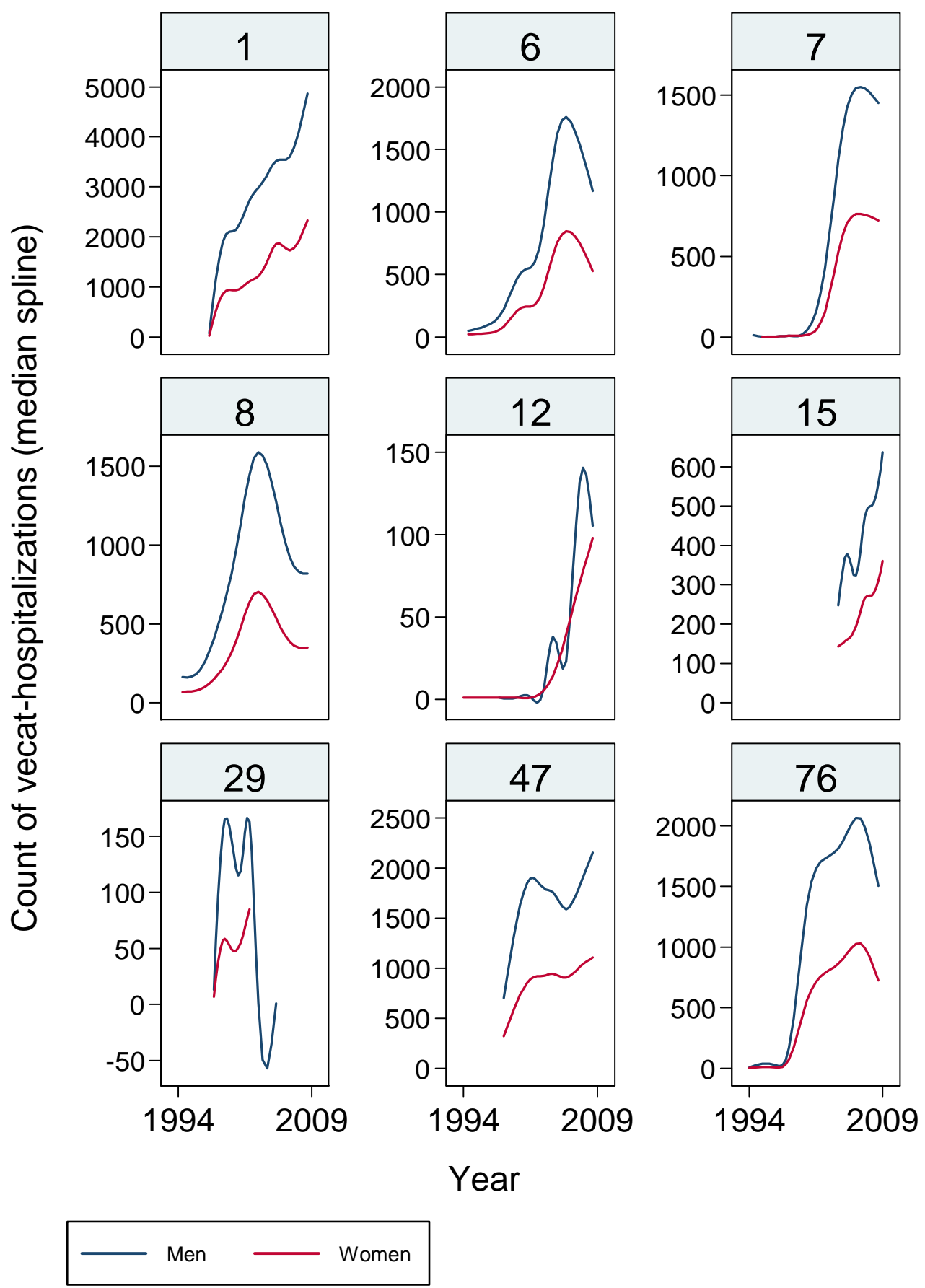

Figure 20: Count of hospitalizations with VECAT (left-sided heart catheterization) as main diagnosis by hospital, 1994-2009 
Hospitalizations with HVCAT by hospital

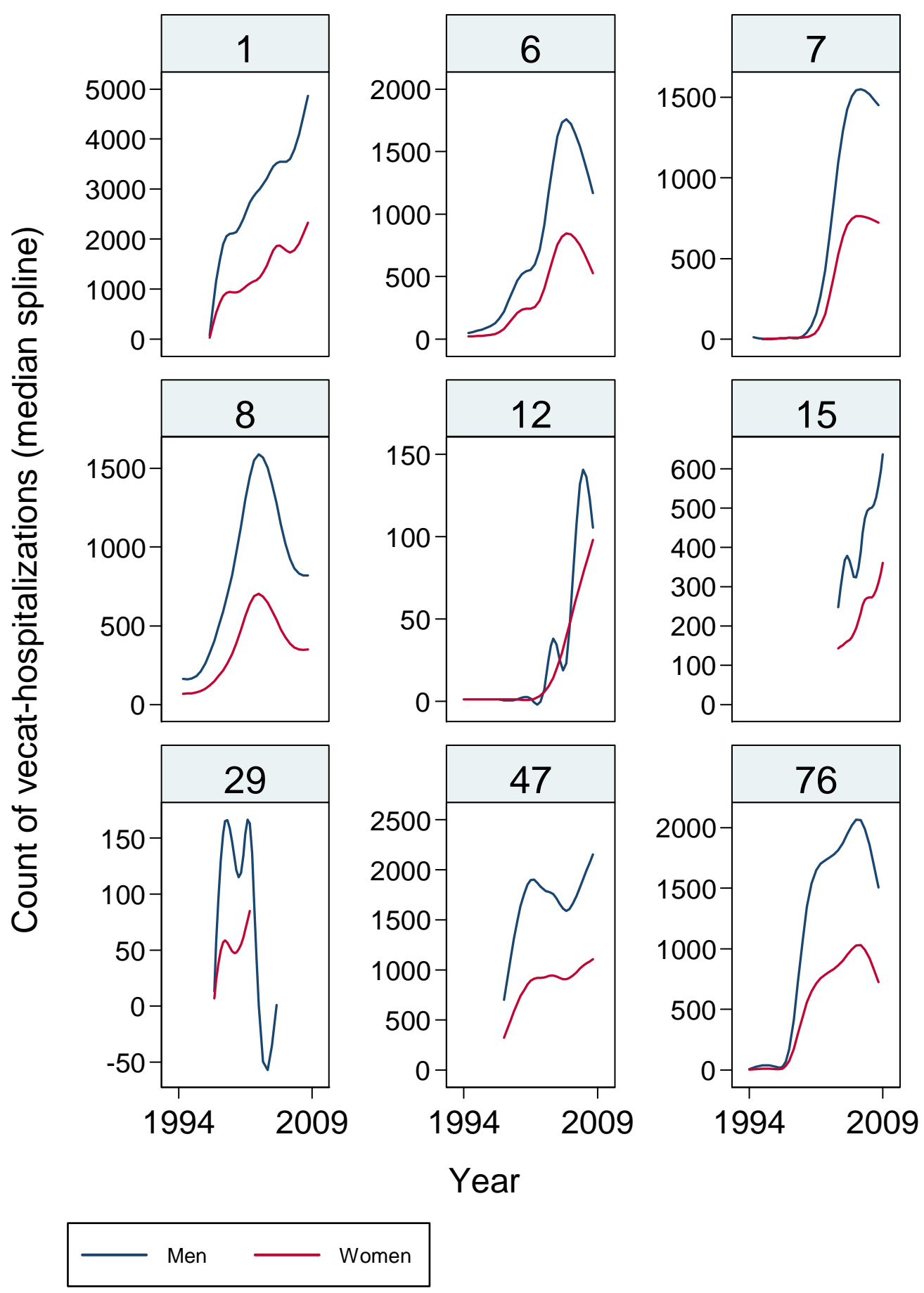

Figure 21: Count of hospitalizations with HVECAT (right or left-sided heart catheterization) as main diagnosis by hospital, 1994-2009 


\section{CONOR Endpoints}

\section{Definition of endpoint-groups for CONOR participants}

Table 12: Definition of diagnosis groups for hospitalizations and deaths

\begin{tabular}{|c|c|c|c|}
\hline $\begin{array}{l}\text { Short } \\
\text { name }\end{array}$ & Name & ICD9-codes & ICD10-codes \\
\hline CVD & Cardiovascular disease & $390-459$ & $100-199$ \\
\hline CHD & Coronary heart disease & $410-414$ & $120-125$ \\
\hline CHD2 & Coronary heart disease 2 & $\begin{array}{l}410-414,798.1,798.2 \\
798.9\end{array}$ & I20-125, I46.1, R96, R98 \\
\hline CHD3 & Coronary heart disease 3 & $410-414,798.1,798.2$ & 120-|25,|46.1, R96 \\
\hline SD & Sudden death 1 & $\begin{array}{l}427.5,798.1,798.2 \\
798.9\end{array}$ & 146.1, R96, R98 \\
\hline SD2 & Sudden death 2 & $427.5,798.1,798.2$ & 146.1, R96 \\
\hline AMI & Acute myocardial infarction & 410 & 121,122 \\
\hline AMI2 & Acute myocardial infarction 2 & $\begin{array}{l}410,427.5,798.1,798.2 \\
798.9\end{array}$ & I21, I22, 146.1, R96, R98 \\
\hline AMI3 & Acute myocardial infarction 3 & $410,427.5,798.1,798.2$ & $121,122,146.1, \mathrm{R} 96$ \\
\hline AMI4 & Acute myocardial infarction 4 & $410,798.1,798.2$ & $121,122, \mathrm{R} 96$ \\
\hline AMI5 & Acute myocardial infarction 5 & $410,427.5$ & $121,122,146.1$ \\
\hline MCE & Major Coronary Event & $\begin{array}{l}410,427.5,798.1,798.2 \\
798.9\end{array}$ & $121,122,146.1, \mathrm{R} 96, \mathrm{R} 98$ \\
\hline MCE2 & Major Coronary Event 2 & $410,427.5,798.1,798.2$ & $121,122,146.1, \mathrm{R} 96$ \\
\hline ACS & Acute coronary syndrome & 410,411 & $120.0,121,122$ \\
\hline ACS2 & Acute coronary syndrome 2 & $\begin{array}{l}\text { 410, 411, 427.5, 798.1, } \\
798.2,798.9\end{array}$ & $\begin{array}{l}\text { I20.0, 121, 122, 146.1, } \\
\text { R96, R98 }\end{array}$ \\
\hline ACS3 & Acute coronary syndrome 3 & $\begin{array}{l}\text { 410, 411, 427.5, 798.1, } \\
798.2\end{array}$ & $\begin{array}{l}120.0,121,122,146.1 \\
\text { R96 }\end{array}$ \\
\hline CEREBRO & Cerebrovascular disease & $430-438$ & $160-169$ \\
\hline TOTS & Total stroke & $430-434,436$ & $\begin{array}{l}160-161,163-164 \text { except } \\
163.6\end{array}$ \\
\hline ISCHS & Ischemic stroke & 433,434 & 163 except 163.6 \\
\hline ISCHUC & $\begin{array}{l}\text { Ischemic/unspecified } \\
\text { cerebrovascular disease }\end{array}$ & $\begin{array}{l}433,434,436,437.0 \\
437.1\end{array}$ & $\begin{array}{l}163 \text { except 163.6, } 164 \\
165,166,167.0,167.2\end{array}$ \\
\hline TIA & Transient Ischemic attack & 435 & G45 \\
\hline AA & Aorta aneurism & 441 & 171 \\
\hline PAD & Peripheral artery disease & $\begin{array}{l}\text { 440, } 441 \text { except } 441.7, \\
442,443.9,444\end{array}$ & $170-179$ \\
\hline ASVD & Atherosclerotic disease & $\begin{array}{l}\text { 410-414, 433,434,436, } \\
\text { 437.0, 437.1, } \\
\text { 440, } 441 \text { except } 441.7 \\
442,443.9,444\end{array}$ & $\begin{array}{l}120-125 \\
163 \text { except 163.6, 164, } \\
165,166,167.0,167.2 \\
170-179\end{array}$ \\
\hline HT & Hypertension & 401-405 & $|10-| 15$ \\
\hline AS & Aorta stenosis & 424.1 & $135.0,135.2$ \\
\hline AF & Atrial fibrillation/ flutter & 427.3 & 148 \\
\hline
\end{tabular}




\begin{tabular}{llll}
\hline $\begin{array}{l}\text { Short } \\
\text { name }\end{array}$ & Name & ICD9-codes & ICD10-codes \\
\hline HF & Heart Failure & 428 & I50 \\
DM & Diabetes Mellitus & 250 & E10-E14 \\
CongHeart & Congenital Heart Defects & $745-747$ & Q20-Q28 \\
\hline
\end{tabular}

Table 13: Definition of main groups for underlying causes of death

\begin{tabular}{llll}
\hline Short name & Name & ICD9-codes & ICD10-codes \\
\hline CVD & Cardiovascular disease & $390-459$ & I00-199 \\
\hline CANCER & Cancer & $140-208$ & C00-C97 \\
\hline LUNGCANCER & Lung Cancer & 162 & C33-C34 \\
OTHER & Other diseases & $001-139,210-389,460-$ & A, B, D, E, F, G, H, J, K, \\
& $\begin{array}{l}\text { Violent deaths and } \\
\text { VIOLENT }\end{array}$ & E800-E999 & L, W, X, Y , Q \\
\hline ILLDEFINED & $\begin{array}{l}\text { III-defined causes of } \\
\text { death }\end{array}$ & $780-799$ & R00-R99 \\
\hline
\end{tabular}

Table 14: Definition of treatment groups

\begin{tabular}{llll}
\hline Short name & Name & SIF & NCSP/NCMP \\
\hline PCI & $\begin{array}{l}\text { Percutaneous coronary } \\
\text { intervention }\end{array}$ & $3294,3236,3239$ & FNG \\
CABG & $\begin{array}{l}\text { Coronary artery bypass } \\
\text { grafting }\end{array}$ & $3112-3129$ & FNA, FNB, FNC, FND, \\
& $\begin{array}{l}\text { Coronary } \\
\text { CR }\end{array}$ & $3112-3129$, & FNE, FNF \\
& revascularization & $3294,3236,3239$ & FNA, FNB, FNC, FND, \\
\hline
\end{tabular}




\section{Endpoint variables}

For each group in Table 12 and Table 14 a set of endpoint variables has been generated.

Table 15: Variable Explanation for disease endpoints with the AMI -group as example

\begin{tabular}{|c|c|}
\hline Variable & Explanation \\
\hline exdate & Examination date in CONOR \\
\hline age_ex_days & $\begin{array}{l}\text { Age at examination generated by assuming that all participants are } \\
\text { born on the } 15^{\text {th }} \text { of month_born_co }\end{array}$ \\
\hline age_ex_years & age_ex_days/365.25 \\
\hline ami_death & $\begin{array}{l}\text { 1: Death with AMI as underlying cause of death. } \\
0: \text { Death from other causes or alive at 31DEC2010 }\end{array}$ \\
\hline death_date & Date of death \\
\hline days_death & Days from exdate until death or 31DEC2010 if still alive. \\
\hline age_death_exit_days & Age in days at death or 31DEC2010 if still alive \\
\hline age_death_exit_years & age_death_exit_days/365.25 \\
\hline ami_hosp & $\begin{array}{l}\text { 1: Hospitalization with AMI as main or secondary diagnosis after exdate } \\
0: \text { No AMI-hospitalization between exdate and 31DEC2009. }\end{array}$ \\
\hline ami_hosp_date & Date of first AMI-hospitalization after exdate \\
\hline prev_ami_hosp & $\begin{array}{l}\text { 1: Hospitalization with AMI as main or secondary diagnosis before } \\
\text { exdate. } \\
\text { 0: No AMI-hospitalization in CVDNOR before exdate (NB! CVDNOR does } \\
\text { not have data before } 1994 \text {. Should combine information with data } \\
\text { from CONOR-questionnaire) }\end{array}$ \\
\hline prev_ami_hosp_date & Date of first AMI-hospitalizatino before exdate \\
\hline ami_hospdeath & $\begin{array}{l}\text { 1: AMI-hospitalization or AMI-death between exdate and 31DEC2009 } \\
\text { 0: No AMI-hospitalization or AMI-death between exdate and } \\
\text { 31DEC2009 }\end{array}$ \\
\hline ami_hospdeath_date & $\begin{array}{l}\text { Date of first AMI(hospitalization or death) between exdate and } \\
\text { 31DEC2009 }\end{array}$ \\
\hline days_ami_hospdeath & $\begin{array}{l}\text { Days from exdate until first AMI or until death if death from other } \\
\text { causes or until 31DEC2009 if still alive and ami_hospdeath }=0 \text {. }\end{array}$ \\
\hline age_ami_hospdeath_days & Age in days at first AMI between exdate and 31DEC2009 \\
\hline age_ami_hospdeath_years & age_ami_hospdeath_days/365.25 \\
\hline
\end{tabular}


Table 16: Variable Explanation for treatment endpoints with $\mathrm{PCl}$ as example

\begin{tabular}{|c|c|}
\hline Variable & Explanation \\
\hline pci_hosp & $\begin{array}{l}\text { 1: Hospitalization with PCl between exdate and } \\
\text { 31DEC2009 } \\
\text { 2: No PCI-hospitalization between exdate and } \\
\text { 31DEC2009 }\end{array}$ \\
\hline pci_hosp_date & $\begin{array}{l}\text { Date of first PCl-hospitalization between exdate } \\
\text { and 31DEC2009 }\end{array}$ \\
\hline prev_pci_hosp & $\begin{array}{l}\text { 1: Hospitalization with PCI before exdate. } \\
\text { 0: No PCI-hospitalization before exdate. }\end{array}$ \\
\hline prev_pci_hosp_date & Date of first $\mathrm{PCl}$-hospitalization before exdate. \\
\hline days_pci_hosp & $\begin{array}{l}\text { Days from exdate until first } \mathrm{PCl} \text {-hospitalization or } \\
\text { until death if pci_hosp }=0 \text { or until 31DEC2009 if } \\
\text { still alive and pci hosp }=0 \text {. }\end{array}$ \\
\hline age_pci_hosp_days & Age in days at first $\mathrm{PCl}$-hospitalization \\
\hline age_pci_hosp_years & age_pci_hosp_days/365.25 \\
\hline
\end{tabular}




\section{Count of fatal endpoints}

Table 17: Count of deaths by underlying cause. Participants are followed for fatal endpoints until 31DEC2010.

\begin{tabular}{|c|c|c|c|c|}
\hline & $\begin{array}{r}\text { Men, n } \\
(\%)^{1}\end{array}$ & $\begin{array}{r}\text { Women, } \mathbf{n} \\
(\%)^{2}\end{array}$ & $\begin{array}{r}\text { Total, } \mathbf{n} \\
(\%)^{3}\end{array}$ & $\begin{array}{r}\text { Percent of } \\
\text { total } \\
\text { deaths }\end{array}$ \\
\hline CONOR Participants & 87358 & 93195 & $180553^{4}$ & \\
\hline \multicolumn{5}{|l|}{ Main groups of deaths } \\
\hline Total deaths & $13729(15.7)$ & $10442(11.2)$ & $24171(13.4)$ & 100.0 \\
\hline Cardiovascular disease & $5139(5.9)$ & $3918(4.2)$ & $9057(5.0)$ & 37.5 \\
\hline Cancer & $4385(5.0)$ & $3125(3.4)$ & $7510(4.2)$ & 31.1 \\
\hline Other diseases & $3002(3.4)$ & $2580(2.8)$ & $5582(3.1)$ & 23.1 \\
\hline Accidents/ violent deaths & $662(0.8)$ & $413(0.4)$ & $1075(0.6)$ & 4.4 \\
\hline Ill-defined deaths & $541(0.6)$ & $406(0.4)$ & $947(0.5)$ & 3.9 \\
\hline \multicolumn{5}{|l|}{ Sub-groups of deaths } \\
\hline Coronary Heart Disease & $2625(3.0)$ & $1440(1.6)$ & $4065(2.3)$ & 16.8 \\
\hline Acute Myocardial Infarction & $1798(2.1)$ & $952(1.0)$ & $2750(1.5)$ & 11.4 \\
\hline Acute Myocardial Infarction 2 & $2061(2.4)$ & $1114(1.2)$ & $3175(1.8)$ & 13.1 \\
\hline Acute Myocardial Infarction 3 & $2031(2.3)$ & $1095(1.2)$ & $3126(1.7)$ & 12.9 \\
\hline Acute Myocardial Infarction 4 & $2021(2.3)$ & $1088(1.2)$ & $3109(1.7)$ & 12.9 \\
\hline Acute Myocardial infarction 5 & $1808(2.1)$ & $959(1.0)$ & $2767(1.5)$ & 11.4 \\
\hline Sudden Death & $263(0.3)$ & $162(0.2)$ & $425(0.2)$ & 1.8 \\
\hline Sudden Death 2 & $233(0.3)$ & $143(0.2)$ & $376(0.2)$ & 1.6 \\
\hline Cerebrovascular disease & $1069(1.2)$ & $1148(1.2)$ & $2217(1.2)$ & 9.2 \\
\hline Total Stroke & $852(1.0)$ & $947(1.0)$ & $1799(1.0)$ & 7.4 \\
\hline Ischemic stroke & $202(0.2)$ & $184(0.2)$ & $386(0.2)$ & 1.6 \\
\hline $\begin{array}{l}\text { Ischemic and unspecified } \\
\text { stroke }\end{array}$ & $613(0.7)$ & $703(0.8)$ & $1316(0.7)$ & 5.4 \\
\hline Transient Ischemic attack & $12(0.01)$ & $12(0.01)$ & $24(0.01)$ & 0.1 \\
\hline Aorta aneurism & $274(0.3)$ & $137(0.2)$ & $411(0.2)$ & 1.7 \\
\hline Peripheral Artery Disease & $394(0.5)$ & $242(0.3)$ & $636(0.4)$ & 2.6 \\
\hline Atherosclerotic disease & $3643(4.2)$ & $2394(2.6)$ & $6037(3.3)$ & 25.0 \\
\hline Hypertension & $110(0.1)$ & $125(0.1)$ & $235(0.1)$ & 1.0 \\
\hline Aorta stenosis & $89(0.1)$ & $126(0.1)$ & $215(0.1)$ & 0.9 \\
\hline Atrial fibrillation/flutter & $159(0.2)$ & $214(0.2)$ & $373(0.2)$ & 1.5 \\
\hline Heart Failure & $295(0.3)$ & $312(0.3)$ & $607(0.3)$ & 2.5 \\
\hline Diabetes Mellitus & $203(0.2)$ & $163(0.2)$ & $366(0.6)$ & 1.5 \\
\hline Congenital Heart Defects & $3(0.003)$ & $4(0.004)$ & $7(0.004)$ & 0.03 \\
\hline Lung Cancer & $956(1.1)$ & $512(0.6)$ & $1468(0.01)$ & 6.1 \\
\hline
\end{tabular}

\footnotetext{
${ }^{1}$ Percentage of male participants

${ }^{2}$ Percentage of female participants

${ }^{3}$ Percentage of total number of participants

${ }^{4} 173243$ unique persons since 7309 have participated more than once
} 


\section{Count of combined endpoints, hospitalization or death}

Table 18: Count of combined endpoints, hospitalization or death. Participants are followed for combined endpoints until 31DEC2009.

\begin{tabular}{|lrrr}
\hline & Men, n (\%) & Women, n (\%) & Total, n (\%) \\
\hline CONOR Participants & 87358 & 93195 & $180553^{5}$ \\
\hline Disease endpoints & & & \\
\hline Cardiovascular disease & $27060(31.0)$ & $21377(22.9)$ & $48437(26.8)$ \\
\hline Coronary heart disease & $13577(15.5)$ & $7375(7.9)$ & $20952(11.6)$ \\
\hline Coronary heart disease 2 & $13783(15.8)$ & $7486(8.0)$ & $21269(11.8)$ \\
\hline Coronary heart disease 3 & $13760(15.8)$ & $7472(8.0)$ & $21232(11.8)$ \\
\hline Acute myocardial infarction & $6561(7.5)$ & $3174(3.4)$ & $9735(5.4)$ \\
\hline Major Coronary Event & $6791(7.8)$ & $3296(3.5)$ & $10087(5.6)$ \\
\hline Major Coronary Event 2 & $6764(7.7)$ & $3281(3.5)$ & $10045(5.6)$ \\
\hline Acute coronary syndrome & $7915(9.1)$ & $3978(4.3)$ & $11893(6.6)$ \\
\hline Acute coronary syndrome 2 & $8143(9.3)$ & $4099(4.4)$ & $12242(6.8)$ \\
\hline Acute coronary syndrome 3 & $8117(9.3)$ & $4084(4.4)$ & $12201(6.8)$ \\
\hline Cerebrovascular disease & $6214(7.1)$ & $4937(5.3)$ & $11151(6.2)$ \\
\hline Total stroke & $4935(5.7)$ & $3991(4.3)$ & $8926(4.9)$ \\
\hline Ischemic stroke & $3858(4.4)$ & $2949(3.2)$ & $6807(3.8)$ \\
\hline Ischemic/unspecified cerebrovascular disease & $4618(5.3)$ & $3673(3.9)$ & $8291(4.6)$ \\
\hline Transient Ischemic attack & $1562(1.8)$ & $1315(1.4)$ & $2877(1.6)$ \\
\hline Aorta aneurism & $1521(1.7)$ & $489(0.5)$ & $2010(1.1)$ \\
\hline Peripheral artery disease & $3484(4.0)$ & $1868(2.0)$ & $5352(3.0)$ \\
\hline Atherosclerotic disease & $17517(20.1)$ & $10784(11.6)$ & $28301(15.7)$ \\
\hline Hypertension & $11536(13.2)$ & $10810(11.6)$ & $22346(12.4)$ \\
\hline Aorta stenosis & $1177(1.4)$ & $1084(1.2)$ & $2261(1.3)$ \\
\hline Atrial fibrillation/flutter & $69117.9)$ & $4283(4.6)$ & $11194(6.2)$ \\
\hline Heart Failure & $4411(5.1)$ & $3157(3.4)$ & $7568(4.2)$ \\
\hline Diabetes Mellitus & $4549(5.2)$ & $3479(3.7)$ & $8028(4.4)$ \\
\hline Congenital Heart Defects & $156(0.2)$ & $185(0.2)$ & $341(0.2)$ \\
\hline Treatment endpoints & & & \\
\hline Percutaneous coronary intervention & $3310(3.8)$ & $1228(1.3)$ & $4538(2.5)$ \\
\hline Coronary artery bypass graft & $2272(2.6)$ & $695(0.8)$ & $2967(1.7)$ \\
\hline Coronary revascularization & $5255(6.0)$ & $1795(1.9)$ & $7050(3.9)$ \\
\hline
\end{tabular}

\footnotetext{
${ }^{5} 173243$ unique persons since 7309 have participated more than once
} 


\section{Appendix A: Requirement Specification for retrieval of hospital data}

\section{ICD-9 diagnosis codes}

\section{Beskrivelse}

Ondartet svulst i hjerte/mediastinum

Godartet svulst i hjertet

Diabetes mellitus

Flebitt, tromboflebitt og trombose i hjernens venøse sinus

Diabetes retinopati 362

Sykdommer i sirkulasjonssystemet

$\emptyset$ dem, proteinuri og komplikasjoner som følge av hypertensive lidelser under svangerskap, fødsel

og barseltid (puerperium) 648

Venøse komplikasjoner under svangerskap 668.1

Dyp tromboflebitt før fødselen 671.3

Dyp tromboflebitt etter fødselen

Annen flebitt og trombose Cerebral venetrombose

Flebitt i.n.a., Trombose i.n.a.

Obstetrisk blodpropp, puerperal lungeemboli i.n.a

I.n.a. Plutselig død av ukjent årsak i barselseng

Medfødte misdannelser i sirkulasjonssystemet

Koma og sopor

Synkope og kollaps

Forbigående lammelse av ekstremitet

$\varnothing$ dem

Cyanose

Symptomer fra det kardiovaskulære system Eksl.: Hjertesvikt i.n.a. (428.9)

Dyspné

Andre intratorakale organer 


\begin{tabular}{|c|c|}
\hline $\begin{array}{l}\text { Uspesifikke og unormale resultater av funksjonsundersøkelser } \\
\text { Hjerte og kar }\end{array}$ & 794.3 \\
\hline Unormal blodtrykksmåling, uten diagnose; hypertensjon & 796.2 \\
\hline Unormal blodtrykksmåling, uten diagnose; hypotensjon & 796.3 \\
\hline $\begin{array}{l}\text { Ubestemte og ukjente årsaker til sykdom og død } \\
\text { Plutselig død }\end{array}$ & 798.1 \\
\hline $\begin{array}{l}\text { Ubestemte og ukjente årsaker til sykdom og død } \\
\text { Død av ukjent årsak mindre enn } 24 \text { timer etter symptomenes begynnelse }\end{array}$ & 798.2 \\
\hline $\begin{array}{l}\text { Ubestemte og ukjente årsaker til sykdom og død } \\
\text { Funnet } d \varnothing d\end{array}$ & 798.9 \\
\hline $\begin{array}{l}\text { Andre ubestemte og ukjente årsaker til død } \\
\text { Respirasjonssvikt }\end{array}$ & 799.1 \\
\hline $\begin{array}{l}\text { Andre ubestemte og ukjente årsaker til død } \\
\text { Andre ubestemte tilstander }\end{array}$ & 799.8 \\
\hline $\begin{array}{l}\text { Andre ubestemte og ukjente årsaker til død } \\
\text { Annen ukjent og uspesifisert årsak }\end{array}$ & 799.9 \\
\hline Mekaniske komplikasjoner i forbindelse med kardial protese, implantat eller graft & 996.0 \\
\hline Mekaniske komplikasjoner i forbindelse med annen vaskulær protese, implantat eller graft & 996.1 \\
\hline Andre komplikasjoner i forbindelse med innvortes protese, implantat eller graft & 996.7 \\
\hline $\begin{array}{l}\text { Komplikasjoner som påvirker spesifiserte organsystemer, ikke klassifisert andre steder } \\
\text { Sentralnevøse komplikasjoner }\end{array}$ & 997.0 \\
\hline $\begin{array}{l}\text { Komplikasjoner som påvirker spesifiserte organsystemer, ikke klassifisert andre steder } \\
\text { Hjertekomplikasjoner }\end{array}$ & 997.1 \\
\hline $\begin{array}{l}\text { Komplikasjoner som påvirker spesifiserte organsystemer, ikke klassifisert andre steder } \\
\text { Perifere vaskulære komplikasjoner }\end{array}$ & 997.2 \\
\hline $\begin{array}{l}\text { Personer med potensiell helserisiko i forbindelse med personlig eller familiens sykehistorie } \\
\text { Personlig sykehistorie om bestemte andre sykdommer } \\
\text { Sykdommer i hjertekarsystemet }\end{array}$ & V12.5 \\
\hline $\begin{array}{l}\text { Personer med potensiell helserisiko i forbindelse med personlig eller familiens sykehistorie } \\
\text { Annen personlig sykehistorie om helserisiko } \\
\text { Kirurgiske inngrep på hjertet og de store kar }\end{array}$ & V15.1 \\
\hline $\begin{array}{l}\text { Personer med tilstand som påvirker deres helse } \\
\text { Organer eller vev erstattet med transplantat } \\
\text { Hjerte }\end{array}$ & V42.1 \\
\hline $\begin{array}{l}\text { Personer med tilstand som påvirker deres helse } \\
\text { Organer eller vev erstattet med transplantat } \\
\text { Hjerteklaffer }\end{array}$ & V42.2 \\
\hline $\begin{array}{l}\text { Personer med tilstand som påvirker deres helse } \\
\text { Organer eller vev erstattet på annen måte }\end{array}$ & V43.2 \\
\hline
\end{tabular}




\begin{tabular}{|lc|}
\hline Hjerte & \\
\hline $\begin{array}{l}\text { Personer med tilstand som påvirker deres helse } \\
\text { Organer eller vev erstattet på annen måte } \\
\text { Hjerteklaffer }\end{array}$ & \\
\hline $\begin{array}{l}\text { Personer med tilstand som påvirker deres helse } \\
\text { Organer eller vev erstattet på annen måte } \\
\text { Blodårer }\end{array}$ & $\mathrm{V} 43.3$ \\
\hline $\begin{array}{l}\text { Personer med tilstand som påvirker deres helse } \\
\text { Tilstand med kunstig åpning }\end{array}$ & $\mathrm{V} 44.0$ \\
\hline $\begin{array}{l}\text { Trakeostomi } \\
\text { Personer med tilstand som påvirker deres helse }\end{array}$ & $\mathrm{V} 45.0$ \\
\hline $\begin{array}{l}\text { Andre postoperative tilstander } \\
\text { Kardial pacemaker in situ }\end{array}$ & $\mathrm{V} 47.2$ \\
\hline $\begin{array}{l}\text { Personer med tilstand som påvirker deres helse } \\
\text { Andre problemer med indre organer } \\
\text { Andre kardio-respiratoriske problemer }\end{array}$ & $\mathrm{V} 53.3$ \\
\hline $\begin{array}{l}\text { Personer som kontakter helsetjenesten for spesielle behandlingsopplegg og etterbehandling } \\
\text { Tilpasning eller korreksjon av andre hjelpemidler } \\
\text { Pacemaker }\end{array}$ & $\mathrm{V} 71.7$ \\
\hline $\begin{array}{l}\text { Kontakt med personer uten kjent diagnose i forbindelse med enkelt- eller masseundersøkelse } \\
\text { Observasjon og evaluering av suspekte tilstander } \\
\text { Observasjon for suspekt kardiovaskulær sykdom }\end{array}$ & \\
\hline
\end{tabular}




\section{ICD-10 diagnosis codes}

\section{Beskrivelse}

Hjertesykdom forårsaket av meningokokksykdom

A39.5

Ondartet svulst i hjerte

Overlappende svulst i hjerte, mediastinum og brysthinne

Godartet svulst i hjertet

D15.1

Diabetes mellitus

E10-E14

Intrakraniell og intraspinal flebitt og tromboflebitt

Idiopatisk perifer autonom nevropati

Andre ryggmargssykdommer;

Vaskulære myelopatier

Karokklusjoner i netthinne (retina)

Sykdommer i sirkulasjonssystemet

$\emptyset$ dem, proteinuri og komplikasjoner som følge av hypertensive lidelser under svangerskap,

fødsel og barseltid (puerperium)

Venøse komplikasjoner under svangerskap

Dyp flebotrombose under svangerskap

Venøse komplikasjoner under svangerskap

Cerebral ven $\emptyset$ s trombose under svangerskap

Venøse komplikasjoner under svangerskap

Andre spesifiserte venøse komplikasjoner under svangerskapet

Venøse komplikasjoner under svangerskap

Uspesifisert venøs komplikasjon under svangerskap

Diabetes mellitus under svangerskap

Hjertekomplikasjoner som følge av anestesi under svangerskap

Hjertekomplikasjoner som følge av anestesi under fødsel og forløsning

Andre komplikasjoner ved fødsel og forløsning, ikke klassifisert annet sted

Andre komplikasjoner til obstetrisk kirurgi og inngrep (cerebral anoksi / hjertekomplik.)

Venøse komplikasjoner i barseltid

Obstetrisk blodproppemboli

Hjertekomplikasjoner i forbindelse med anestesi i barseltid

Komplikasjoner i barseltid , ikke klassifisert annet sted

Kardiomyopati i barseltid

Obstetrisk død av uspesifisert årsak 095

Sykdommer i sirkulasjonssystemet som kompliserer svangerskap, fødsel og barseltid

099.4




\begin{tabular}{|c|c|}
\hline (tilstander i 100-199). & \\
\hline Medfødte misdannelser i sirkulasjonssystemet & Q20-Q28 \\
\hline $\begin{array}{l}\text { Symptomer, tegn og unormale kliniske funn } \\
\text { Unormale hjerteslag }\end{array}$ & R00-R03 \\
\hline $\begin{array}{l}\text { Åndedrettsabnormiteter } \\
\text { Dyspné }\end{array}$ & R06.0 \\
\hline Smerte i hals og bryst & R07 \\
\hline $\begin{array}{l}\text { Andre symptomer og tegn med tilknytning til sirkulasjons- og åndedrettssystemet } \\
\text { Respirasjonsstans }\end{array}$ & R09.2 \\
\hline $\begin{array}{l}\text { Andre symptomer og tegn med tilknytning til sirkulasjons- og åndedrettssystemet } \\
\text { Andre spesifiserte symptomer og tegn med tilknytning til sirkulasjons- og åndedrettssystemet }\end{array}$ & R09.8 \\
\hline Cyanose & R23.0 \\
\hline $\begin{array}{l}\text { Symptomer og tegn med tilknytning til kognisjon, persepsjon, emosjonell tilstand og adferd: } \\
\text { Somnolens, stupor og koma }\end{array}$ & R40 \\
\hline Synkope og kollaps & R55 \\
\hline Sjokk, ikke klassifisert annet sted (ICD-8/9 inkludere septisk / hypovolemisk sjokk) & R57 \\
\hline$\varnothing$ dem, ikke klassifisert annet sted & R60 \\
\hline $\begin{array}{l}\text { Unormale funn ved diagnostisk avbildning av andre kroppsstrukturer } \\
\text { Hjerte og karsirkulasjon }\end{array}$ & R93.1 \\
\hline $\begin{array}{l}\text { Unormale resultater av funksjonsstudier } \\
\text { Hjerte og kar }\end{array}$ & R94.3 \\
\hline $\begin{array}{l}\text { Dårlig definerte og ukjente dødsårsaker } \\
\text { Annen plutselig død av ukjent årsak }\end{array}$ & R96 \\
\hline $\begin{array}{l}\text { Dårlig definerte og ukjente dødsårsaker } \\
\text { Funnet } \mathrm{d} \emptyset \mathrm{d}\end{array}$ & R98 \\
\hline $\begin{array}{l}\text { Dårlig definerte og ukjente dødsårsaker } \\
\text { Andre dårlig definerte og uspesifiserte dødsårsaker }\end{array}$ & R99 \\
\hline Komplikasjoner til inngrep, ikke klassifisert annet sted (blødning, sjokk, infeksjon osv) & T81 \\
\hline Komplikasjoner ved proteser, implantater og transplantater i hjerte og blodkar & T82 \\
\hline $\begin{array}{l}\text { Funksjonssvikt og avstøtning av transplanterte organer og vev } \\
\text { Funksjonssvikt og avstøtning av hjertetransplantat }\end{array}$ & T86.2 \\
\hline $\begin{array}{l}\text { Funksjonssvikt og avstøtning av transplanterte organer og vev } \\
\text { Funksjonssvikt og avstøtning av hjerte- lungetransplantat }\end{array}$ & T86.3 \\
\hline $\begin{array}{l}\text { Skade på pasient som følge av svikt ved medisinsk utstyr i diagnostisk eller terapeutisk bruk } \\
\text { Svikt ved kardiovaskulært utstyr }\end{array}$ & Y71 \\
\hline Pasientreaksjon som følge av medisinsk eller kirurgisk prosedyre, og senere komplikasjon til & Y83.2 \\
\hline
\end{tabular}


slik prosedyre, hvis selve prosedyren forløp uten anmerkning om skade

Kirurgisk prosedyre med anastomose, "bypass" eller kartransplantasjon

Pasientreaksjon som følge av medisinsk eller kirurgisk prosedyre, og senere komplikasjon til Y84.0

slik prosedyre, hvis selve prosedyren forløp uten anmerkning om skade

Hjertekateterisering

Medisinsk observasjon og vurdering ved mistanke om sykdommer og tilstander

Observasjon ved mistanke om hjerteinfarkt

Medisinsk observasjon og vurdering ved mistanke om sykdommer og tilstander;

Observasjon ved mistanke om hjertekarsykdommer

Kontakt med helsetjenesten for justering og kontroll av implantert hjelpemiddel;

Justering og kontroll av hjertepacemaker

Kontakt med helsetjenesten ved status etter transplantert organ og vev

Status etter transplantert hjerte

Kontakt med helsetjenesten ved status etter transplantert organ og vev

Status etter transplantert hjerte og lunger

Kontakt med helsetjenesten ved status med implantater og transplantater i hjerte og blodkar

Z95

\section{Procedure codes}

\begin{tabular}{|c|c|c|}
\hline Beskrivelse & $\begin{array}{l}\text { Klassifikasjon av } \\
\text { operasjoner, } 3 . \\
\text { Versjon, } 1995 \\
\text { Kodeverk: SIF95 }\end{array}$ & $\begin{array}{l}\text { Klassifikasjon av } \\
\text { medisinske prosedyrer og } \\
\text { kirurgiske inngrep } 2006^{6} \\
\text { Kodeverk: NCMP og NCSP } \\
2006\end{array}$ \\
\hline Operasjoner på hjertet og de store kar & 3000-3299 & $\mathrm{F}$ \\
\hline $\begin{array}{l}\text { Operasjoner på perifere blodkar og } \\
\text { lymfesystemet }\end{array}$ & $8800-8899$ & $P$ \\
\hline $\begin{array}{l}\text { Operasjoner på halskar, kode benyttet før } \\
1995\end{array}$ & 0220 & \\
\hline $\begin{array}{l}\text { Operasjoner på halskar, kode benyttet før } \\
1995\end{array}$ & 0230 & \\
\hline $\begin{array}{l}\text { Operasjoner på halskar, kode benyttet før } \\
1995\end{array}$ & 0231 & \\
\hline $\begin{array}{l}\text { Operasjoner på halskar, kode benyttet før } \\
1995\end{array}$ & 0249 & \\
\hline Mindre kardiologiske inngrep & & TF, WDAB80 \\
\hline Mindre karkirurgiske inngrep & & TP, KAGD46, KAGD47, KAGD48, \\
\hline
\end{tabular}

${ }^{6}$ Gjeldende fra 01.01.1999, består koden av 5 tegn; to første tegn er alltid bokstaver, to siste er alltid tall. 


\begin{tabular}{|ll|}
\hline & RXGG61 \\
\hline Hjerteundersøkelser & XF \\
\hline $\begin{array}{l}\text { Peroperativ transøsophagela } \\
\text { ultralydsundersøkelse }\end{array}$ & XGX 02 \\
\hline Undersøkelser ved perifer karkirurgi & XP \\
\hline Tilleggskoder til kapittel F & ZF \\
\hline $\begin{array}{l}\text { Ballongdillatasjon (Denne tilleggskoden } \\
\text { benyttes trolig ikke) }\end{array}$ & ZFX 00 \\
\hline Bruk av rotablator & ZFX 01 \\
\hline Bruk av angiojet & ZFX 02 \\
\hline Bruk av aterektomi-instrument & ZFX 03 \\
\hline $\begin{array}{l}\text { Inngrep knyttet til tidligere inngrep til } \\
\text { kapittel F }\end{array}$ & ZSF 00 \\
\hline $\begin{array}{l}\text { Inngrep knyttet til tidligere inngrep til } \\
\text { kapittel P }\end{array}$ & ZSP 00 \\
\hline Behandling av peroperativt hjerteproblem & ZXG \\
\hline $\begin{array}{l}\text { Midlertidige nasjonale særkoder: Åpen } \\
\text { hjertekompresjon (ved hjertestans under } \\
\text { kirurgiske inngrep; se ZXG 10-20) }\end{array}$ & FX2 81 \\
\hline
\end{tabular}




\section{Appendix B: Overview of the linkage process}

FS-systemet: CVDNOR - datainnsamling for UiBs prosjekt:

Cardiovascular Disease in Norway 1994-2009

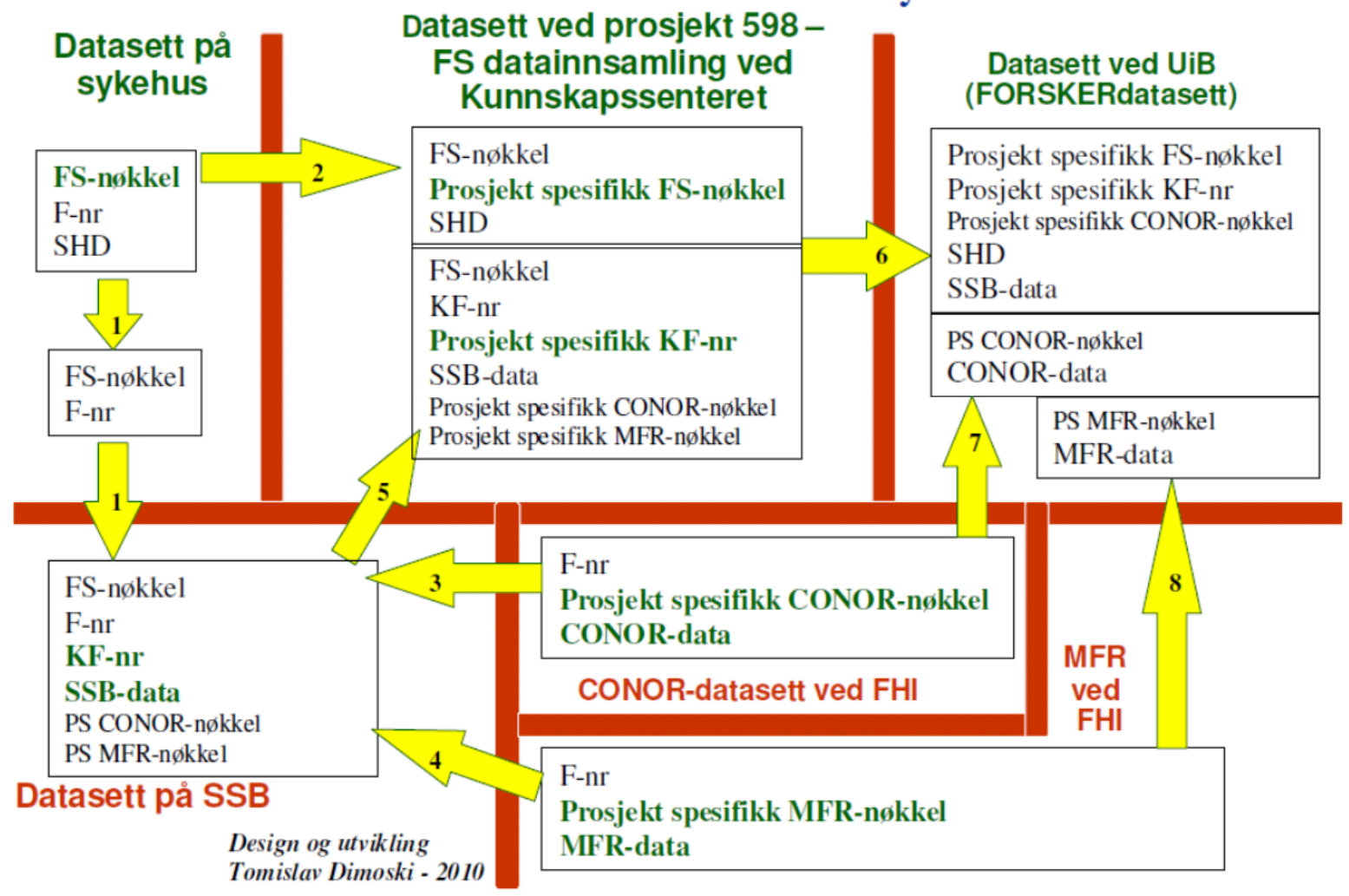




\section{Appendix C: List of hospitals included in the CVDNOR project}

\begin{tabular}{|c|c|c|}
\hline $\begin{array}{l}\text { Institution } \\
\text { number }\end{array}$ & Hospital Name & Health Region \\
\hline 29 & Aker universitetssykehus (inkl. Ski) & Helse Sør- $\varnothing$ st \\
\hline 17 & Akershus universitetssykehus & Helse $S \varnothing r-\varnothing s t$ \\
\hline 28 & Diakonhjemmets sykehus & Helse Sør- Øst \\
\hline 47 & Feiringklinikken & Helse $S \varnothing r-\varnothing$ st \\
\hline 33 & Lovisenberg Diakonale sykehus & Helse $S \varnothing r-\varnothing s t$ \\
\hline 1 & Oslo universitetssykehus HF & Helse Sør- $\varnothing$ st \\
\hline 14 & Sykehuset Innlandet HF & Helse $S \varnothing r-\varnothing s t$ \\
\hline 42 & Sykehuset $\varnothing$ stfold HF & Helse $S \varnothing r-\varnothing$ st \\
\hline 34 & Klinikk Notodden & Helse $S \varnothing r-\varnothing$ st \\
\hline 2 & Klinikk Rjukan & Helse $S \varnothing r-\varnothing$ st \\
\hline 46 & Sykehuset i Vestfold HF & Helse $S \varnothing r-\varnothing$ st \\
\hline 52 & Sykehuset Telemark - Krager $\varnothing$ & Helse $S \varnothing r-\varnothing$ st \\
\hline 39 & Sykehuset Telemark - Skien/Porsgrunn & Helse $S \varnothing r-\varnothing$ st \\
\hline 15 & Sørlandet sykehus HF & Helse $S \varnothing r-\varnothing$ st \\
\hline 4 & Vestre Viken HF & Helse $S \varnothing r-\varnothing$ st \\
\hline 30 & Haraldsplass Diakonale sjukehus & Helse Vest \\
\hline 63 & Haugesund sjukehus & Helse Vest \\
\hline 6 & Helse Bergen HF & Helse Vest \\
\hline 37 & Helse Førde HF & Helse Vest \\
\hline 61 & Odda sjukehus & Helse Vest \\
\hline 7 & Stavanger Universitetssykehus & Helse Vest \\
\hline 62 & Stord sjukehus & Helse Vest \\
\hline 38 & Kristiansund sjukehus & Helse Midt-Norge \\
\hline 45 & Molde sjukehus & Helse Midt-Norge \\
\hline 25 & Orkdal Sjukehus & Helse Midt-Norge \\
\hline 8 & St. Olavs Hospital & Helse Midt-Norge \\
\hline 10 & Sykehuset Levanger & Helse Midt-Norge \\
\hline 23 & Sykehuset Namsos & Helse Midt-Norge \\
\hline 41 & Volda sjukehus & Helse Midt-Norge \\
\hline 9 & Ålesund sjukehus & Helse Midt-Norge \\
\hline 24 & Klinikk Hammerfest & Helse Nord \\
\hline 31 & Klinikk Kirkenes & Helse Nord \\
\hline 35 & Mo i Rana & Helse Nord \\
\hline 40 & Mosjøen & Helse Nord \\
\hline 12 & Nordlandssykehuset, Bod $\varnothing$ & Helse Nord \\
\hline 32 & Nordlandssykehuset, Lofoten & Helse Nord \\
\hline
\end{tabular}




\begin{tabular}{|l|l|l|}
\hline $\begin{array}{l}\text { Institution } \\
\text { number }\end{array}$ & Hospital Name & Health Region \\
\hline 36 & Sandnessjøen & Helse Nord \\
\hline 13 & UNN - Harstad & Helse Nord \\
\hline 27 & UNN - Narvik & Helse Nord \\
\hline $76^{*}$ & UNN - Troms $\varnothing$ & Helse Nord \\
\hline $11^{* *}$ & UNN - Troms $\varnothing^{*}$ & Helse Nord \\
\hline 18 & Vesterålen & Helse Nord \\
\hline
\end{tabular}

* Code used between 1994 and 2007

** Code used in 2008 and 2009 


\section{References}

1. Clench-Aas J, Hofoss D, Rønning O, Helgeland J, Dimoski T, Gulbrandsen P, et al.

Methodological development and evaluation of 30-day mortality as quality indicator for Norwegian hospitals. The Norwegian Knowledge Centre for the Health Services, 2005, p. 179.

2. Naess O, Sogaard AJ, Arnesen E, Beckstrom AC, Bjertness E, Engeland A, et al. Cohort profile: cohort of Norway (CONOR). International journal of epidemiology. 2008; 37: 481-5.

3. Pajunen $\mathrm{P}$, Paakkonen $\mathrm{R}$, Juolevi A, Hamalainen $\mathrm{H}$, Keskimaki I, Laatikainen $\mathrm{T}$, et al. Trends in fatal and non-fatal coronary heart disease events in Finland during 1991-2001. Scandinavian cardiovascular journal : SCJ. 2004; 38: 340-4.

4. Yeh RW, Sidney S, Chandra M, Sorel M, Selby JV and Go AS. Population trends in the incidence and outcomes of acute myocardial infarction. The New England journal of medicine. 2010; 362: 2155-65.

5. Osler M, Rostgaard K, Sorensen TI and Madsen M. The effect of recurrent events on registerbased estimates of level and trends in incidence of acute myocardial infarction. Journal of clinical epidemiology. 1999; 52: 595-600.

6. Tell GS, Nygaard OK, Seifert R, Igland J, Klakegg Y, Juul K, et al. Hjerte-, kar- og slagregisteret Helseregion Vest 1972-2006. Uni Health, 2008.

7. Oyen N, Nygard O, Igland J, Tell GS, Nordrehaug JE, Irgens LM, et al. [Hospital admission rates for cardiovascular diseases in Western Norway, 1992-2001]. Tidsskrift for den Norske laegeforening : tidsskrift for praktisk medicin, ny raekke. 2008; 128: 17-23.

8. Langorgen J, Igland J, Vollset SE, Averina M, Nordrehaug JE, Tell GS, et al. Short-term and long-term case fatality in 11878 patients hospitalized with a first acute myocardial infarction, 19792001: the Western Norway cardiovascular registry. European journal of cardiovascular prevention and rehabilitation : official journal of the European Society of Cardiology, Working Groups on Epidemiology \& Prevention and Cardiac Rehabilitation and Exercise Physiology. 2009; 16: 621-7. 